\title{
A Combined Experimental and Computational Study of Halogen and Hydrogen Bonding in Molecular Salts of 5-Bromocytosine
}

\author{
Massimiliano Aschi ${ }^{1}$ (D) Giorgia Toto Brocchi ${ }^{2}$ and Gustavo Portalone ${ }^{2, *(D)}$ \\ 1 Dipartimento di Scienze Fisiche e Chimiche, Università degli Studi di L'Aquila, Via Vetoio 10, \\ 67100 Coppito, Italy; massimiliano.aschi@univaq.it \\ 2 Dipartimento di Chimica, Università di Roma "La Sapienza", Piazzale Aldo Moro 5, 00185 Roma, Italy; \\ Totobrocchi.1699396@studenti.uniroma1.it \\ * Correspondence: gustavo.portalone@uniroma1.it
}

Citation: Aschi, M.; Toto Brocchi, G.;

Portalone, G. A Combined

Experimental and Computational Study of Halogen and Hydrogen Bonding in Molecular Salts of 5-Bromocytosine. Molecules 2021, 26, 3111. https://doi.org/10.3390/ molecules26113111

Academic Editor: Arnaud Gissot

Received: 3 April 2021

Accepted: 17 May 2021

Published: 23 May 2021

Publisher's Note: MDPI stays neutral with regard to jurisdictional claims in published maps and institutional affiliations.

Copyright: (c) 2021 by the authors. Licensee MDPI, Basel, Switzerland. This article is an open access article distributed under the terms and conditions of the Creative Commons Attribution (CC BY) license (https:// creativecommons.org/licenses/by/ $4.0 /)$.

\begin{abstract}
Although natural or artificial modified pyrimidine nucleobases represent important molecules with valuable properties as constituents of DNA and RNA, no systematic analyses of the structural aspects of bromo derivatives of cytosine have appeared so far in the literature. In view of the biochemical and pharmaceutical relevance of these compounds, six different crystals containing proton-transfer derivatives of 5-bromocytosine are prepared and analyzed in the solid-state by single crystal X-ray diffraction. All six compounds are organic salts, with proton transfer occurring to the $\mathrm{N}_{\text {imino }}$ atom of the pyridine ring. Experimental results are then complemented with Hirshfeld surface analysis to quantitively evaluate the contribution of different intermolecular interactions in the crystal packing. Furthermore, theoretical calculations, based on different arrangements of molecules extracted from the crystal structure determinations, are carried out to analyze the formation mechanism of halogen bonds (XBs) in these compounds and provide insights into the nature and strength of the observed interactions. The results show that the supramolecular architectures of the six molecular salts involve extensive classical intermolecular hydrogen bonds. However, in all but one proton-transfer adducts, weak to moderate $\mathrm{XBs}$ are revealed by $\mathrm{C}-\mathrm{Br} \cdots \mathrm{O}$ short contacts between the bromine atom in the fifth position, which acts as XB donor (electron acceptor). Moreover, the lone pair electrons of the oxygen atom of adjacent pyrimidine nucleobases and/or counterions or water molecules, which acts as XB acceptor (electron donor).
\end{abstract}

Keywords: 5-bromocytosine; modified nucleobases; DNA; biomolecular engineering; molecular recognition; halogen bonding; hydrogen bonding; X-ray diffraction; DFT; QTAIM

\section{Introduction}

Natural or chemical modified nucleobases represent an important class of molecules with considerable properties as constituents of DNA and RNA. These modified nucleobases are profitable to originate new nucleic acid structures, to identify binding sites, and to broaden the suitability of nucleic acids in the field of diagnostics, therapeutics, biomolecular engineering, and nanotechnology [1,2]. Consequently, it is not surprising that in the past couple of decades, considerable attention has been attracted by the role played by noncovalent interactions flanking hydrogen bond (HB) and engaging halogen atoms in the molecular recognition and supramolecular assembly of halo (halogen)-modified nucleobases. As a result, although in these systems HBs remain prevalent among other coexisting noncovalent interactions, the significance of halogen bonds (XBs) today is largely recognized [3-7].

In halogen-bonded complexes, the halogen atom in one molecule can interact favorably with the negative site of an adjacent molecule, due to an attraction between the positively charged site of a covalently bound halogen atom ( $\sigma$-hole) and an electron donor species, 
usually a neutral or ionic Lewis base [8]. However, as the strength of an XB depends on the size and polarizability of the halogen atom, which both increase with the halogen atomic number, $\mathrm{F}$ atom rarely forms halogen bonds, and typically $\mathrm{Cl}, \mathrm{Br}$, and $\mathrm{I}$ atoms are considered in biologically relevant compounds [5].

In DNA polymers, high-resolution structures of complexes with halogenated ligands are uncommon. Nonetheless, among DNA systems showing halo-substituted pyrimidine nucleobases, the structural aspects of XBs have been inferred from experimental and theoretical studies, and bromine and oxygen atoms appear to be the optimal electron acceptors and donors, respectively [5].

As concerns halouracils as constituents of nucleic acids, from a survey in the Protein Data Bank (PDB) [9], crystallographic evidence indicates that 5-bromouracil stabilizes a Holliday junction, a branched DNA structure containing four double-stranded arms joined together, through the formation of a short $\mathrm{Br} \cdots \mathrm{O}$ intermolecular contact, $\approx 3.00 \AA$. This contact corresponds to an $R_{\mathrm{XB}}{ }^{*}\left(R_{\mathrm{XB}}\right.$ is defined as $R_{\mathrm{XB}}=d_{\mathrm{XB}} / d_{\max }$ [10], where $d_{\mathrm{XB}}[\AA]$ is the distance between the donor $X$ and the acceptor atoms $B$, and $d_{\max }$ is the sum of the $\mathrm{vdW}$ radii $[\AA]$ for the $X$ and $B$ interacting atoms [11]) equal to 0.89 . Remarkably, nucleic acid folding is sensitive to the exact position (C5) where the halogenation occurs in the pyrimidine nucleobase [12]. This result agrees with theoretical studies on a halogenated DNA fragment, based on the stacked-X form in the sequence $d\left(C C A G T A C B r^{5} U G G\right)$, which show that nucleotide $\mathrm{C}-\mathrm{Br} \cdots \mathrm{O}-\mathrm{P}$ contact linking 5-bromouracil to an adjacent phosphate oxygen influences the local conformation of the model system and contributes to stabilizing its flexible backbone [13]. Very recently, a comprehensive PDB survey revealed that also moderately strong intramolecular XBs between bromine atoms of 5-bromouracil and oxygen atoms of the backbone phosphate groups can enhance the stability of DNA and RNA molecules [14].

Regarding halo-modified cytosines in nucleic acids, 5-bromoderivatives deserve special attention in epigenetic control of gene expression. Bromine atom can mimic the behavior of a methyl group in DNA-protein interactions, and 5-bromocytosine can result in aberrant methylation of cytosine during replication of DNA, as methyl-binding proteins cannot discriminate methylated from halogenated DNA [15,16]. Moreover, 5bromocytosine can be incorporated into cellular DNA to facilitate DNA-strand breaks and crosslinks upon UV irradiation, and has been proposed for clinical use as a photosensitizer [17]. Due to the capability of this halocytosine to form supramolecular assemblies through $\mathrm{XBs}$ and HBs, it has been shown that the stacking pattern, which allows close contacts between the halogen and the oxygen atoms of two adjacent bases, enhances the stability of hairpin triples DNAs containing 5-bromocytosine [18,19].

It is also well recognized that nucleobases (and halonucleobases) can be protonated at physiological $\mathrm{pH}$, and the protonation affects the biological functions of nucleic acids, as a consequence of changes in the hydrogen-bonding characteristics of base pairing. Numerous studies, based on the investigation of crystal and solution structures, demonstrate that protonated nucleobases are implicated in RNA catalysis and control folding and stability of RNA and DNA, due to their capacity to form specific noncovalent intermolecular interactions [20,21]. A remarkable example of structural versatility due to the nucleobase protonation is offered by the intercalated motif ( $i$-motif) in DNA. In the $i$-motif, based on the association of cytosine molecules protonated under neutral or slightly acidic conditions to form neutral cytosine-hemi-protonated cytosine base pairs $\left(\mathrm{C} \mathrm{CH}^{+}\right)$, two parallelstranded duplexes are held together in an antiparallel orientation by intercalated $\mathrm{C}: \mathrm{CH}^{+}$ pairs [22-25]. Noteworthy, by decreasing the proton affinity of the N3 atom, 5-halogenation of 1-methylcytosine does not destroy the $i$-motif in DNA, but may alter the number of trinucleotide repeats required to induce the structural conversion from Watson and Crick (WC) base-pairing to the $i$-motif association [26].

Surprisingly, in spite of its potential interest, little is known about the structural aspects of 5-bromocytosine and its protonated derivative in the solid state. A search in the Cambridge Crystallographic Database (CSD version 5.42, February 2021 update) [27] for neutral 
and protonated unsubstituted 5-bromocytosine gave five hits. From this survey, three hits contained neutral 5-bromocytosine (refcodes: BCYTGA, BRCPDG, and BRCYTS [28-30]), and only two hits contained $\mathrm{N}_{\text {imino }}(\mathrm{N} 3)$-protonated 5-bromocytosine, (refcodes: HABKEA and NUZKEY [31,32]). Adopting a cutoff value of 0.96 for the interaction ratio $R_{\mathrm{XB}}$, three structures (BCYTGA, BRCPDG, and HABKEA) exhibited weak almost linear XBs (C-X $\cdots B$ bond angle $\geq 155^{\circ}$ ) in which bromine atoms act as $\mathrm{XB}$ donors, and the strongest $\mathrm{XB}$ interaction was found in one of the two structures containing the 5-bromocytosinium cation (HABKEA, $R_{\mathrm{XB}}=0.88$ ).

In the light of the above observations, we believed important to conduct a systematic structure analysis for molecular salts involving $\mathrm{N}_{\text {imino-protonated }}$ 5-bromocytosine and simple counterions, which can both act as hydrogen and/or halogen bond donor/acceptor. In particular, the present study aims to determine qualitatively and quantitatively the interactions of protonated 5-bromocytosines with themselves, counterions, and water molecules by a combined experimental and computational approach.

For this purpose, we prepared and crystallized six different molecular salts containing proton-transfer derivatives of 5-bromocytosine (Scheme 1).<smiles>[2H]c1[nH]c(=O)[n+]([2H])c(NN)c1Br</smiles>

Scheme 1. Chemical components of the compounds (I-VI) investigated in this study.

5-bromocytosine, as cytosine [33], can exist in different tautomeric forms, which can induce modifications in the normal base pairing. Although the possibility of tautomerization of 5-bromocytosine has been calculated to be much less likely than that of cytosine, analyses of FTIR and Raman spectra of this halonucleobase, supported by ab initio and DFT calculations, demonstrate the prevalence in the gas phase of the aromatic amino-2-hydroxy cis tautomer among the nine possible tautomeric forms originated by proton migration involving the $\mathrm{O}, \mathrm{N} 1, \mathrm{~N} 3$, and $\mathrm{N}_{\text {amino }}$ atoms. On the contrary, by using a tetrameric fragment of 5-bromocytosine as a simplified model of the crystal unit cell, only the simulated spectra of tetramer nonaromatic $1 \mathrm{H}$-amino-oxo forms satisfactorily reproduce the experimental spectra in the solid state [34]. These results confirm the preference for only one tautomeric form in the crystal of 5-bromocytosine, i.e., the tautomer, which is the most frequently present in nucleic acids [35].

Due to the halo substitution at the fifth position, 5-bromocytosine, as a base, is moderately stronger than cytosine $\left(p \mathrm{~K}_{\mathrm{a} 1}=3.04\right.$ and 4.61 , respectively [36]), and in the presence of acids, can be easily protonated at the N3 atom. In the solid state, the existence of neutral or charged molecular adducts formed through proton transfer reactions can be foreseen by the $\Delta p \mathrm{~K}_{\mathrm{a}}$ value ( $p \mathrm{~K}_{\mathrm{a}}$ (conjugate acid of the base) $-p \mathrm{~K}_{\mathrm{a}}$ (acid), $p \mathrm{~K}_{\mathrm{a}}$ 's are for an aqueous solution at $25^{\circ} \mathrm{C}$ ). For $\Delta p \mathrm{~K}_{\mathrm{a}}>3$, salts of the type $\mathrm{B}^{+}-\mathrm{H}^{\cdots} \mathrm{A}^{-}$are expected, whereas $\Delta p \mathrm{~K}_{\mathrm{a}}<0$ will almost exclusively result in neutral component $\mathrm{B} \cdots \mathrm{H}-\mathrm{A}$ cocrystal. Nevertheless, as in the case of molecular salts $(\mathbf{V})$ and $(\mathbf{V I})\left(\Delta p \mathrm{~K}_{\mathrm{a}}=3.04-1.96=1.08\right.$ and $3.04-1.27=1.77$, respectively), when $0<\Delta p \mathrm{~K}_{\mathrm{a}}<3$ the $\mathrm{pH}$ dependence to control crystal formation seems inappropriate and overlap of the cocrystal to the salt continuum is observed [37]. It should be noted that in a crystal, due to the anisotropic molecular environment, polarization via strong HBs can play a key role in determining the formation of a salt or a cocrystal. Therefore, as HBs may be considered the partially activated precursors to proton-transfer reactions [38], to predict the salt or cocrystal formation, additional factors, other than $\Delta p \mathrm{~K}_{\mathrm{a}}$, 
such as dynamic proton disorder or temperature dependency of proton transfer, should be considered [39]. Recently, the dependency of proton-transfer reactions on temperature has been investigated in molecular systems showing short, strong hydrogen bonds, i.e., HBs shorter than $2.55 \AA$, (SSHBs) [40]. To this purpose, the crystal structures of eight molecular complexes, exhibiting SSHBs and containing $\mathrm{N}, \mathrm{N}$-dimethylurea or isonicotinamide coupled with organic acid coformers, have been determined by multitemperature single crystal synchrotron X-ray diffraction in the range 100-350 K. Noteworthy, two of the eight complexes examined, (1:1) N,N-dimethylurea/2,4-dinitrobenzoic acid and (2:1) isonicotinamide/phthalic acid, showed temperature dependency of proton-transfer processes across HBs. Indeed, in both of them, transition occurs between the salt (100 K) and the cocrystal (300-350 K), and an almost complete proton migration to the acidic coformer was found in the neutral adducts.

The supramolecular assembly of the six molecular salts was, thus, investigated in the solid state through single crystal X-ray diffraction. Two different computational approaches were then employed: Hirshfeld surface and decomposed 2D-fingerprint plots, to quantitively evaluate the contribution of different intermolecular interactions in the crystal packing [41]; Bader's quantum theory of atoms-in-molecules (QTAIM) [42], to provide a more quantitative estimation of the energies and some of the topological features of supramolecular contacts which involve hydrogen and halogen atoms in the formation of the complex environment of such biochemical models.

This article considers a continuation of our long interest in the design and construction of supramolecular architectures of neutral and protonated pyrimidine nucleobases [43-53] and in experimental/computational analyses of simple biological systems exhibiting halogen bonding via alternative donors, i.e., halogen-bond donors not boosted by fluorination of the skeletal structure to which the halogen-bond donors are attached $[10,54,55]$.

\section{Results and Discussion}

\subsection{Structural Analysis}

In this section, we report the crystal structure analysis for all the investigated systems accompanied by the computational QTAIMS analysis aimed at quantitatively describe the localized HBs and XBs. To this purpose, we have first investigated the actual existence of bond critical points (rank 3 and signature -1 ), hereafter simply termed as CPs, in correspondence to the pair interactions that emerged from the crystallographic structural analysis. Subsequently, for each $\mathrm{CP}$, we have evaluated the topological and energetic features following the criterion by Espinosa et al. [56,57]. For the halogen bond interactions, the energy was estimated using a slightly different approach proposed by Tsirelson [58]. The balance between the Lagrangian kinetic energy $\mathrm{G}(\mathbf{r})$ and the potential energy density $\mathrm{V}(\mathbf{r})$ at the $\mathrm{CP}$ were then utilized for quantifying the noncovalent character $(-\mathrm{G} / \mathrm{V}>1)$ of all the corresponding pair interactions.

5-Bromocytosinium chloride, (I), crystallizes in the orthorhombic space group Pbca in the cation/anion ratio 1:1, but the asymmetric unit consists of four $1 H, 3 H$-5-bromocytosinium cations protonated at the N3 atom, four chloride anions and one water molecule of crystallization joined together to form one-dimensional multicomponent planar aggregate (Figure 1a). The occurrence of more than one molecule in the asymmetric unit of ionic compounds is rather unusual $[59,60]$, but a similar situation for $\mathrm{N}_{\text {imino-protonated 5- }}$ bromocytosines have been encountered in the crystal structure of NUZKEY, which crystallizes with three 5-bromocytosinium cations, a hexachloro-platinum(IV) anion, one chloride anion and a water molecule in the asymmetric unit. 


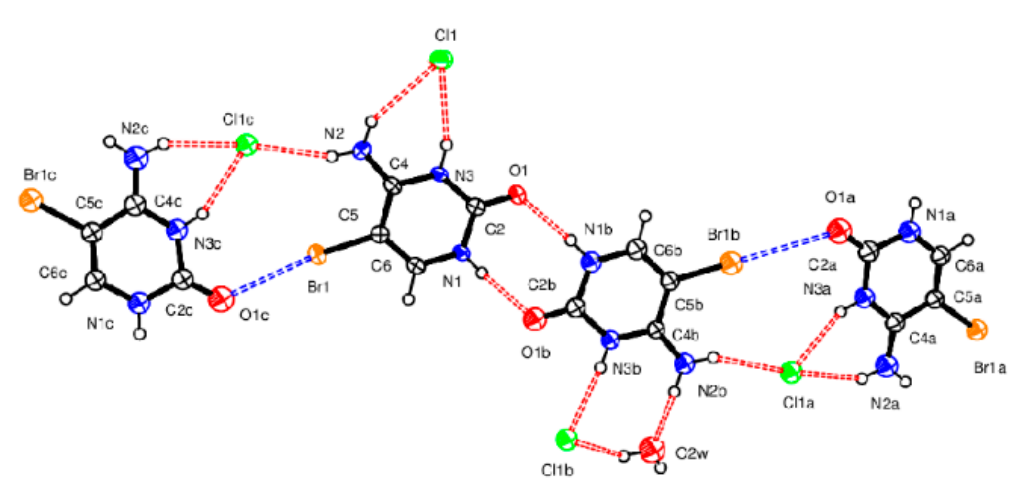

(a)

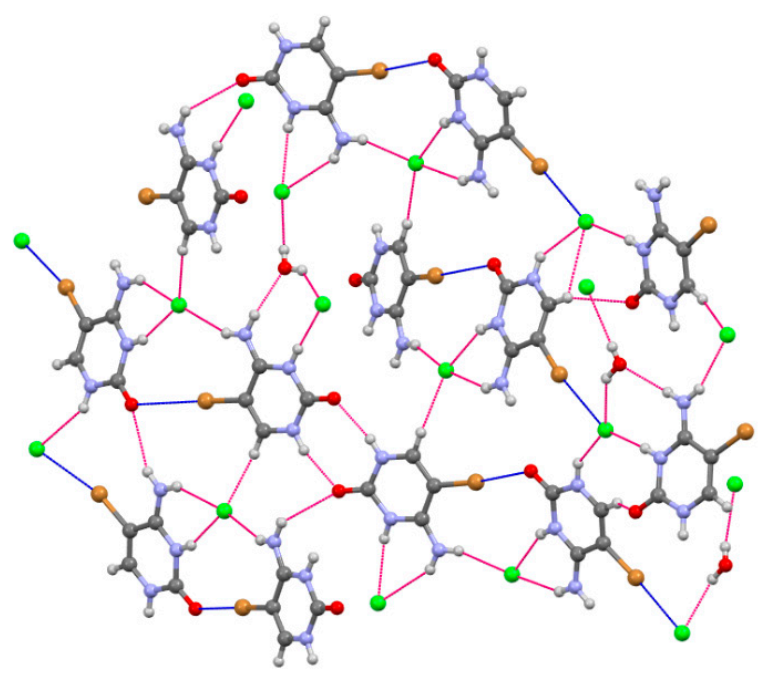

(b)

Figure 1. (a) The asymmetric unit of compound (I), showing the adopted atom-numbering scheme. Displacement ellipsoids are at the $50 \%$ probability level. $\mathrm{H}$ atoms are shown as small spheres of arbitrary radii. Hydrogen bonding is shown as red dashed lines. Halogen bonding is shown as blue dashed lines. (b) Part of the crystal structure of (I). All atoms are shown as small spheres of arbitrary radii. Hydrogen bonding is shown as red dashed lines. Halogen bonding is shown as blue dashed lines.

In the crystal packing of (I), shown in Figure $1 \mathrm{~b}$, in the planar aggregates, a pair of 5-bromocytosinium cations are linked together by $\mathrm{N}-\mathrm{H} \cdots \mathrm{O}$ hydrogen bonds from the $\mathrm{CONH}$ pyrimidinium groups forming a cyclic hydrogen-bonded ring motif represented by graph-set notation $R^{2}{ }_{2}(8)$ [61]. These ion pairs are further connected into a zigzag chain via $\mathrm{N}-\mathrm{H} \cdots \mathrm{Cl}^{-}$hydrogen bonds and two almost linear $\mathrm{C}-\mathrm{Br} \cdots \mathrm{O}$ contacts $(3.03 \AA$, $165^{\circ}$, and $3.26 \AA, 175^{\circ}$ ) involving the carbonyl oxygen atom of adjacent peripheral 5bromocytosinium cations, to give $1 \mathrm{D}$ chains. The $\mathrm{XB}$ ratios $R_{\mathrm{XB}}$ vary between 0.90 and 0.96 , indicating weak interaction strength. In this respect, the $\mathrm{XB}$ interaction energies (between 1.5 and $2.0 \mathrm{kcal} / \mathrm{mol}$ ) and $-\mathrm{G}(\mathbf{r}) / \mathrm{V}(\mathbf{r})$ ratio (between 1.2 and 1.3), evaluated based on topological analysis on the corresponding CPs, clearly confirm the low, but not negligible strength of these interactions, as well as their genuine noncovalent character. These chains are then united by $\mathrm{N}-\mathrm{H}^{\cdots} \mathrm{Cl}^{-}, \mathrm{N}^{+}-\mathrm{H}^{\cdots} \mathrm{Cl}^{-}, \mathrm{N}-\mathrm{H} \cdots \mathrm{O}_{\mathrm{w}}$ and $\mathrm{O}_{\mathrm{w}}-\mathrm{H}^{\cdots} \mathrm{Cl}^{-}$ hydrogen bonds and two $\mathrm{C}-\mathrm{Br}^{\cdots} \mathrm{Cl}^{-}$contacts involving $\mathrm{Cl}^{-}$ions $\left(3.07 \AA, 171^{\circ}, R_{\mathrm{XB}}=0.86\right.$ and $3.22 \AA, 165^{\circ}, R_{\mathrm{XB}}=0.90$, respectively) into sheets. In correspondence with the latter interactions, CPs have been localized by the topological analysis with an estimated interaction energy of $1.2 \mathrm{kcal} / \mathrm{mol}$. No relevant intermolecular HBs involving the $\mathrm{Br}$ atom were observed (Table 1). From the topological analysis, all the HBs turn out to be characterized by $-\mathrm{G}(\mathbf{r}) / \mathrm{V}(\mathbf{r})$ close to unity with interaction energies varying from 3.0 to $10.0 \mathrm{kcal} / \mathrm{mol}$. In particular, rather strong interactions are found for all the $\mathrm{N}^{+}-\mathrm{H}^{\cdots} \mathrm{Cl}^{-}$, and although to a lesser extent, even $\mathrm{N}-\mathrm{H}^{\cdots} \mathrm{Cl}^{-} \mathrm{HBs}$. Rather surprisingly, our calculations have revealed significantly $E_{\text {int }}$ (Internal Energy) values also for the HBs involving uncharged $\mathrm{N} 1-\mathrm{H} 1 \cdots \mathrm{O} 1 \mathrm{~B}$ and N1B-H1B $\cdots$ O1. The latter result can be partially rationalized based on the relatively high value of the Laplacian of the density observed for the corresponding pair interactions. 
Table 1. Hydrogen-bond geometry $\left(\AA,^{\circ}\right)$ and topological analysis for compound $(\mathbf{I}) . \mathrm{E}_{\text {int }}$ is reported in $\mathrm{kcal} / \mathrm{mol}$. For additional details concerning QTAIMS results see Table S1 in the Supporting Information.

\begin{tabular}{|c|c|c|c|c|c|c|}
\hline$D-\mathrm{H} \cdots A$ & $D-\mathrm{H}$ & $\mathbf{H} \cdots A$ & $D \cdots A$ & $D-\mathbf{H} \cdots A$ & $-G(r) / V(r)$ & $E_{\text {int }}$ \\
\hline $\mathrm{N} 2-\mathrm{H} 2 \mathrm{~A} \cdots \mathrm{Cl} 1$ & 0.86 & 2.63 & $3.400(7)$ & 150.1 & 1.07 & 3.0 \\
\hline $\mathrm{N} 2-\mathrm{H} 2 \mathrm{~B} \cdots \mathrm{Cl} C \mathrm{C}$ & 0.86 & 2.40 & $3.224(6)$ & 160.9 & 1.01 & 5.1 \\
\hline $\mathrm{N} 1-\mathrm{H} 1 \cdots \mathrm{O} 1 \mathrm{~B}$ & $0.81(10)$ & $2.01(10)$ & $2.808(8)$ & $169(11)$ & 0.98 & 9.2 \\
\hline $\mathrm{N} 3-\mathrm{H} 3 \cdots \mathrm{Cl} 1$ & 0.86 & 2.41 & $3.230(6)$ & 159.5 & 0.94 & 7.2 \\
\hline $\mathrm{N} 2 \mathrm{~A}-\mathrm{H} 2 \mathrm{~A} 1 \cdots \mathrm{Cl} 1 \mathrm{~A}$ & 0.86 & 2.39 & $3.163(7)$ & 149.1 & 0.98 & 5.2 \\
\hline $\mathrm{N} 2 \mathrm{~A}-\mathrm{H} 2 \mathrm{~A} 2 \cdots \mathrm{O} 1 \mathrm{~A}^{\mathrm{i}}$ & 0.86 & 2.58 & $3.379(9)$ & 155.9 & 1.16 & 1.6 \\
\hline $\mathrm{N} 1 \mathrm{~A}-\mathrm{H} 1 \mathrm{~A} \cdots \mathrm{Cl1}$ ii & 0.86 & 2.63 & $3.375(7)$ & 146.1 & 1.08 & 3.5 \\
\hline $\mathrm{N} 3 \mathrm{~A}-\mathrm{H} 3 \mathrm{~A} \cdots \mathrm{Cl1A}$ & $0.83(8)$ & $2.28(8)$ & $3.062(6)$ & $160(8)$ & 0.88 & 8.1 \\
\hline $\mathrm{N} 2 \mathrm{~B}-\mathrm{H} 2 \mathrm{~B} 1 \cdots \mathrm{O} 2_{\mathrm{w}}$ & 0.86 & 2.06 & $2.862(9)$ & 154.1 & 0.94 & 7.2 \\
\hline $\mathrm{N} 2 \mathrm{~B}-\mathrm{H} 2 \mathrm{~B} 2 \cdots \mathrm{Cl} 1 \mathrm{~A}$ & 0.86 & 2.39 & $3.201(6)$ & 157.6 & 0.99 & 5.7 \\
\hline $\mathrm{N} 1 \mathrm{~B}-\mathrm{H} 1 \mathrm{~B} \cdots \mathrm{O} 1$ & 0.86 & 1.98 & $2.822(8)$ & 164.3 & 0.98 & 9.1 \\
\hline $\mathrm{N} 3 \mathrm{~B}-\mathrm{H} 3 \mathrm{~B} \cdots \mathrm{Cl1B}$ & $0.84(9)$ & $2.24(9)$ & $3.078(6)$ & $171(9)$ & 0.81 & 10.1 \\
\hline $\mathrm{N} 2 \mathrm{C}-\mathrm{H} 2 \mathrm{C} 1 \cdots \mathrm{Cl} 1 \mathrm{C}$ & 0.86 & 2.34 & $3.119(7)$ & 151.7 & 0.94 & 6.6 \\
\hline $\mathrm{N} 1 \mathrm{C}-\mathrm{H} 1 \mathrm{C} \cdots \mathrm{Cl1B}$ iii & 0.86 & 2.40 & $3.113(7)$ & 140.1 & 1.08 & 2.6 \\
\hline $\mathrm{N} 3 \mathrm{C}-\mathrm{H} 3 \mathrm{C} \cdots \mathrm{Cl} 1 \mathrm{C}$ & 0.86 & 2.31 & $3.110(6)$ & 154.8 & 0.90 & 7.3 \\
\hline $\mathrm{O} 2_{\mathrm{w}}-\mathrm{H} 2 \mathrm{~A} \cdots \mathrm{Cl} 1 \mathrm{~B}$ & $0.89(12)$ & $2.28(12)$ & $3.056(7)$ & $146(10)$ & 0.95 & 6.5 \\
\hline $\mathrm{O} 2_{\mathrm{W}}-\mathrm{H} 2 \mathrm{~B} \cdots \mathrm{Cl} 1$ iv & $0.71(8)$ & $2.46(8)$ & $3.156(7)$ & $171(9)$ & 0.95 & 5.1 \\
\hline
\end{tabular}

Symmetry codes: ${ }^{\text {i }} x,-y-1 / 2, z+1 / 2 ;{ }^{\text {ii }}-x, y-1 / 2,{ }^{\text {iii }}-x, y-1 / 2$; ${ }^{\text {iv }}-z+5 / 2, x, y, z+1$.

5-Bromocytosinium bromide, (II), crystallizes in the monoclinic space group $C 2 / c$, and the asymmetric unit consists of one $1 \mathrm{H}, 3 \mathrm{H}$-5-bromocytosinium cation protonated at the N3 atom, one bromide anion, and one water molecule of crystallization (Figure 2a).

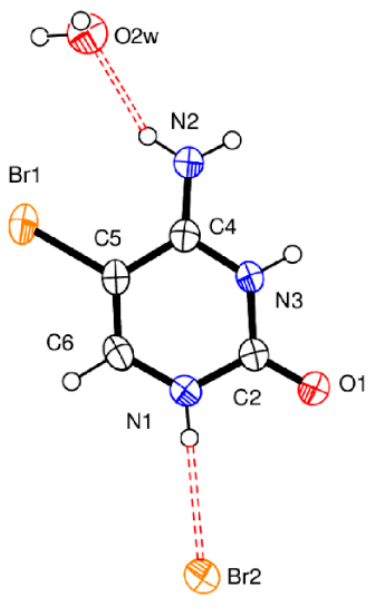

(a)

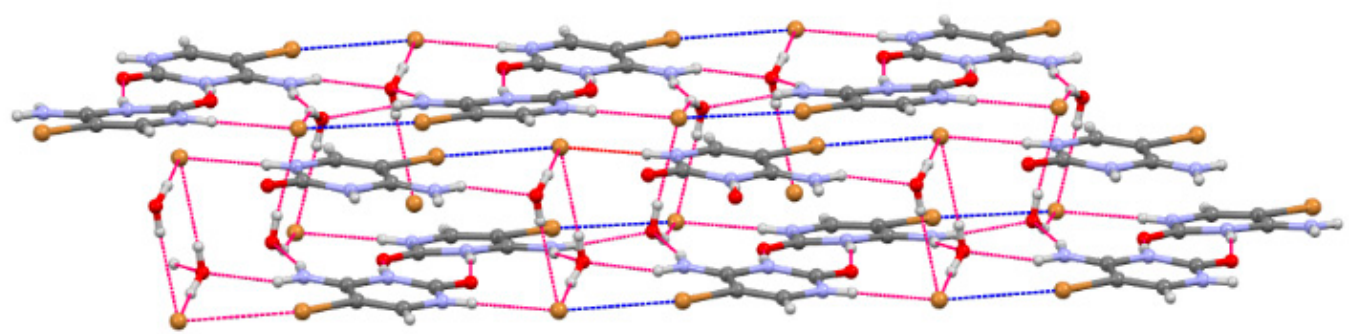

(b)

Figure 2. (a) The asymmetric unit of compound (II), showing the adopted atom-numbering scheme. Displacement ellipsoids are at the $50 \%$ probability level. $\mathrm{H}$ atoms are shown as small spheres of arbitrary radii. Hydrogen bonding is shown as red dashed lines. (b) Part of the crystal structure of (II). All atoms are shown as small spheres of arbitrary radii. Hydrogen bonding is shown as red dashed lines. Halogen bonding is shown as blue dashed lines.

The packing of (II) is shown in Figure 2b. Pairs of 5-bromocytosinium cations are linked together by equivalent $\mathrm{N}^{+}-\mathrm{H} \cdots \mathrm{O}$ hydrogen bonds, which are significantly shorter than normal $\mathrm{N}-\mathrm{H} \cdots \mathrm{O}$ intermolecular interactions (Table 2). These pairs then assemble in layers held together by $\mathrm{N}-\mathrm{H} \cdots \mathrm{O}_{\mathrm{w}}$ of $\mathrm{R}^{2}{ }_{4}(8)$ graph motif involving the amino group of one protonated nucleobase and a nearby oxygen atom of a water molecule, and by $\mathrm{N}-\mathrm{H} \cdots \mathrm{Br}^{-}$ and $\mathrm{O}_{\mathrm{w}}-\mathrm{H}^{\cdots} \mathrm{Br}^{-}$hydrogen bonds to reconstruct the 3D network. All the HBs found in the crystal are confirmed by the topological analyses, which also indicates interaction energies in the range 3.0-9.0 kcal/mol. C-Br $\cdots$ O interactions do not emerge from the crystal struc- 
ture analysis nor the topological analysis. On the other hand, weak $\left(R_{\mathrm{XB}}=0.96\right)$ and almost linear $\mathrm{C}-\mathrm{Br} \cdots \mathrm{Br}^{-}$contacts $\left(3.52 \AA, 160^{\circ}\right)$ involving $\mathrm{Br}^{-}$counterions are present in the crystal and are also localized and characterized by topological analysis as relatively weak $\left(\mathrm{E}_{\mathrm{int}}=1.5 \mathrm{kcal} / \mathrm{mol}\right)$ and markedly noncovalent interactions $(-\mathrm{G}(\mathrm{r}) / \mathrm{V}(\mathrm{r})>1)$. Moreover, in this case, as expected, the strongest interactions turn out to be in correspondence with the HBs involving the $\mathrm{N}^{+}-\mathrm{H}$ moiety.

Table 2. Hydrogen-bond geometry $\left(\AA,^{\circ}\right)$ and topological analysis for compound (II). $\mathrm{E}_{\text {int }}$ is reported in $\mathrm{kcal} / \mathrm{mol}$. For additional details concerning QTAIMS results see Tables S2-S4 in the Supporting Information.

\begin{tabular}{|c|c|c|c|c|c|c|}
\hline $\mathrm{D}-\mathrm{H} \cdots \mathrm{A}$ & $\mathrm{D}-\mathrm{H}$ & $\mathbf{H} \cdots A$ & $\mathrm{D} \cdots \mathrm{A}$ & $\mathbf{D}-\mathbf{H} \cdots \mathbf{A}$ & $-\mathrm{G}(\mathrm{r}) / \mathrm{V}(\mathrm{r})$ & $E_{\text {int }}$ \\
\hline $\mathrm{N} 2-\mathrm{H} 2 \mathrm{~A} \cdots \mathrm{O} 2_{\mathrm{w}}{ }^{\mathrm{i}}$ & 0.86 & 2.00 & $2.831(4)$ & 163.4 & 0.96 & 6.2 \\
\hline $\mathrm{N} 2-\mathrm{H} 2 \mathrm{~B} \cdots \mathrm{O} 2_{\mathrm{w}}$ & 0.86 & 2.09 & $2.881(4)$ & 152.3 & 0.99 & 7.5 \\
\hline $\mathrm{N} 1-\mathrm{H} 1 \cdots \mathrm{Br} 2$ & $0.83(4)$ & $2.43(4)$ & $3.268(3)$ & $179(3)$ & 0.88 & 5.3 \\
\hline $\mathrm{N} 3-\mathrm{H} 3 \cdots \mathrm{O} 1^{\mathrm{ii}}$ & $0.86(4)$ & $1.91(4)$ & $2.754(4)$ & $171(4)$ & 1.04 & 8.6 \\
\hline $\mathrm{O} 2{ }_{\mathrm{W}}-\mathrm{H} 2 \mathrm{~A} \cdots \mathrm{Br} 2{ }^{\mathrm{iii}}$ & $0.73(5)$ & $2.51(5)$ & $3.241(4)$ & $173(5)$ & 0.97 & 4.6 \\
\hline $\mathrm{O} 2{ }_{\mathrm{W}}-\mathrm{H} 2 \mathrm{~B} \cdots \mathrm{Br} 2^{\text {iv }}$ & $0.93(6)$ & $2.61(6)$ & $3.475(3)$ & $155(5)$ & 1.08 & 3.0 \\
\hline
\end{tabular}

Symmetry codes: ${ }^{\mathrm{i}}-x+1, y,-z-1 / 2{ }^{\text {ii }}-x, y,-z-1 / 2 ;{ }^{\text {iii }}-x+1 / 2,-y+1 / 2,-z$; $^{\text {iv }} x+1, y, z$.

5-Bromocytosinium nitrate, (III), crystallizes in the triclinic space group $P-1$ in the cation/anion ratio 1:1. As already mentioned above, for compound (I) and NUZKEY, multiple molecules are present in the asymmetric unit. Four $1 H, 3 H$-5-bromocytosinium cations protonated at the N3 atom, four nitrate anions, and two water molecules of crystallization are joined together to form a multicomponent aggregate (Figure 3a).

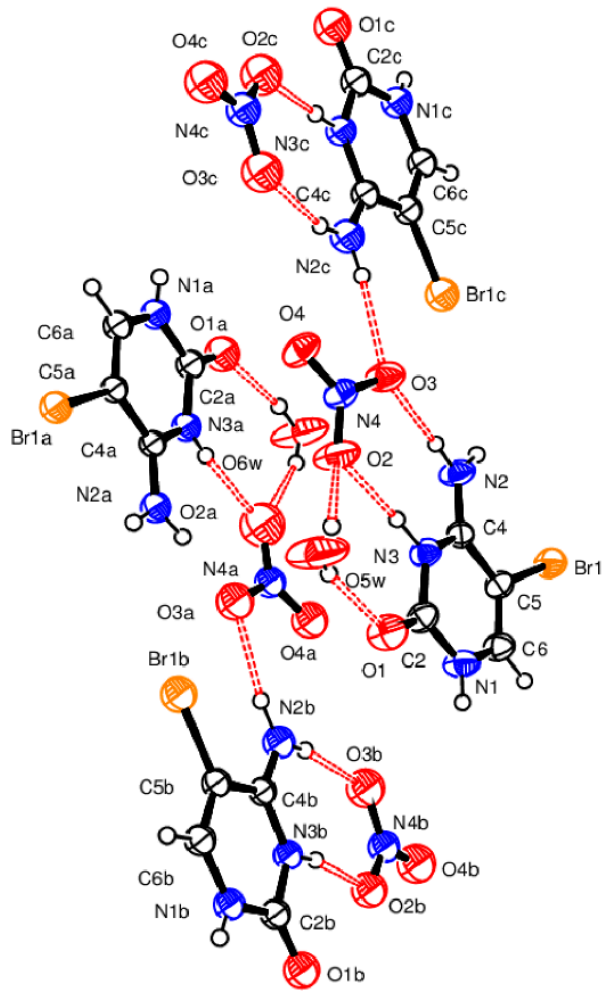

(a)
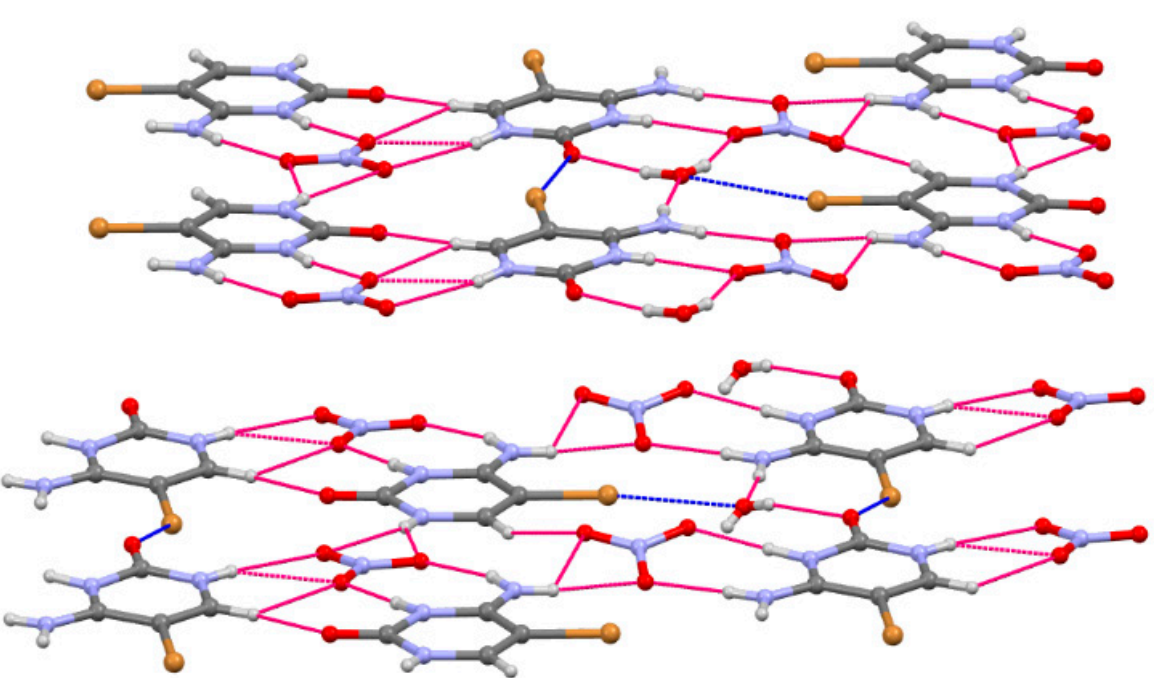

(b)

Figure 3. (a) The asymmetric unit of compound (III), showing the adopted atom-numbering scheme. Displacement ellipsoids are at the $50 \%$ probability level. $\mathrm{H}$ atoms are shown as small spheres of arbitrary radii. Hydrogen bonding is shown as red dashed lines. (b) Part of the crystal structure of (III). All atoms are shown as small spheres of arbitrary radii. Hydrogen bonding is shown as red dashed lines. Halogen bonding is shown as blue dashed lines. 
The packing of compound (III) is shown in Figure 3b. The ions assemble in layers through $\mathrm{N}-\mathrm{H} \cdots \mathrm{O}^{-}$and $\mathrm{N}^{+}-\mathrm{HO}^{-}$hydrogen bonds (Table 3). For all of these HBs, the topological analysis has allowed us to locate as many CPs. The corresponding values of $-\mathrm{G}(\mathrm{r}) / \mathrm{V}(\mathrm{r})$ and $\mathrm{E}_{\text {int }}$, falling in the range 0.9-1.2 and 3.0-8.0 kcal/mol, respectively, describe these pair interactions as genuine noncovalent and rather stable HBs. As expected, the highest $\mathrm{E}_{\text {int }}$ values are found in correspondence with the $\mathrm{N}^{+}-\mathrm{H} \cdots \mathrm{O}$ interactions. There are two kinds of $\mathrm{C}-\mathrm{Br} \cdots \mathrm{O}$ interactions (see also Table S6 in the Supplementary Information). The first one involves two carbonyl oxygen atoms $\left(3.05 \AA, 157^{\circ}, R_{X \mathrm{~B}}=0.90\right.$ and $3.16 \AA$, $150^{\circ}, R_{\mathrm{XB}}=0.94$, respectively), and according to QTAIMS analysis, is characterized by a rather high $-\mathrm{G}(\mathbf{r}) / \mathrm{V}(\mathbf{r})$ values (1.20 and 1.22) and by an appreciable interaction energy (3.6 and $2.4 \mathrm{kcal} / \mathrm{mol}$ ). The second kind of $\mathrm{C}-\mathrm{Br} \cdots \mathrm{O}$ interactions involves two oxygen atoms of water molecules $\left(2.97 \AA, 164^{\circ}, R_{\mathrm{XB}}=0.76\right.$ and $3.03 \AA, 161^{\circ}, R_{\mathrm{XB}}=0.78$, respectively), and similarly to the previous case, has revealed an appreciable interaction energy of 2.9 and $2.1 \mathrm{kcal} / \mathrm{mol}$, respectively. No relevant intermolecular HBs involving the $\mathrm{Br}$ atom were observed. On the other hand, topological analysis has also located (see Table S7 in the Supplementary Information) quantitatively relevant noncovalent interlayers interactions $(-\mathrm{G}(\mathbf{r}) / \mathrm{V}(\mathbf{r})$ close to 1.0$)$ involving $\mathrm{N} 4, \mathrm{O} 2$, and $\mathrm{O} 3$ atoms of nitrate anions with a relatively high $E_{\text {int }}$ (between 7.0 and $8.0 \mathrm{kcal} / \mathrm{mol}$ ).

Table 3. Hydrogen-bond geometry $\left(\AA^{\circ},^{\circ}\right)$ and topological analysis for compound (III). $\mathrm{E}_{\text {int }}$ is reported in kcal/mol. For additional details concerning QTAIMS results see Tables S5-S7 in the Supporting Information.

\begin{tabular}{|c|c|c|c|c|c|c|}
\hline$D-\mathbf{H} \cdots A$ & $D-\mathbf{H}$ & $\mathbf{H} \cdots A$ & $D \cdots A$ & $D-\mathbf{H} \cdots A$ & $-G(r) / V(r)$ & $E_{\text {int }}$ \\
\hline $\mathrm{N} 2-\mathrm{H} 2 \mathrm{~A} \cdots \mathrm{O} 3$ & $0.83(3)$ & $2.03(3)$ & $2.851(3)$ & $173(3)$ & 0.96 & 7.7 \\
\hline $\mathrm{N} 2-\mathrm{H} 2 \mathrm{~B} \cdots \mathrm{O} 5_{\mathrm{w}}{ }^{\mathrm{i}}$ & $1.00(5)$ & $1.89(5)$ & $2.887(4)$ & $175(4)$ & 1.00 & 6.3 \\
\hline $\mathrm{N} 1-\mathrm{H} 1 \cdots \mathrm{O} 4 \mathrm{C}^{\mathrm{ii}}$ & $0.79(3)$ & $2.53(3)$ & $3.306(4)$ & $171(3)$ & 1.02 & 3.0 \\
\hline $\mathrm{N} 3-\mathrm{H} 3 \cdots \mathrm{O} 2$ & $0.92(3)$ & $1.91(3)$ & $2.824(3)$ & $176(3)$ & 0.95 & 8.5 \\
\hline $\mathrm{C} 6-\mathrm{H} 6 \cdots \mathrm{O} 1 \mathrm{C}^{\mathrm{ii}}$ & 0.97 & 2.33 & $3.226(4)$ & 154.2 & 1.21 & 1.8 \\
\hline $\mathrm{N} 2 \mathrm{C}-\mathrm{H} 2 \mathrm{CA} \cdots \mathrm{O} 3$ & $0.84(4)$ & $2.11(4)$ & $2.926(4)$ & $165(3)$ & 0.95 & 5.7 \\
\hline $\mathrm{N} 2 \mathrm{C}-\mathrm{H} 2 \mathrm{CB} \cdots \mathrm{O} 3 \mathrm{C}$ & $0.84(3)$ & $2.16(3)$ & $2.981(4)$ & $166(3)$ & 0.93 & 4.6 \\
\hline $\mathrm{N} 1 \mathrm{C}-\mathrm{H} 1 \mathrm{C} \cdots \mathrm{O} 3 \mathrm{C}^{\mathrm{i}}$ & $0.73(3)$ & $2.38(3)$ & $2.984(3)$ & $142(3)$ & 1.07 & 2.6 \\
\hline $\mathrm{N} 1 \mathrm{C}-\mathrm{H} 1 \mathrm{C} \cdots \mathrm{O} 4 \mathrm{C}^{\mathrm{i}}$ & $0.73(3)$ & $2.33(3)$ & $3.028(4)$ & $163(3)$ & 1.01 & 3.0 \\
\hline $\mathrm{N} 3 \mathrm{C}-\mathrm{H} 3 \mathrm{C} \cdots \mathrm{O} 2 \mathrm{C}$ & $0.97(3)$ & $1.78(3)$ & $2.747(3)$ & $175(3)$ & 0.95 & 8.5 \\
\hline $\mathrm{C} 6 \mathrm{C}-\mathrm{H} 6 \mathrm{C} \cdots \mathrm{O} 4^{\mathrm{i}}$ & 0.97 & 2.47 & $3.385(3)$ & 157.9 & 1.2 & 1.8 \\
\hline $\mathrm{O} 5_{\mathrm{w}}-\mathrm{H} 52 \cdots \mathrm{O} 1$ & $0.89(1)$ & $2.01(2)$ & $2.869(4)$ & $164(4)$ & 1.01 & 6.7 \\
\hline $\mathrm{N} 2 \mathrm{~A}-\mathrm{H} 2 \mathrm{AA} \cdots \mathrm{O} 3 \mathrm{~A}$ & $0.89(3)$ & $1.98(3)$ & $2.864(3)$ & $173(3)$ & 0.96 & 7.8 \\
\hline $\mathrm{N} 2 \mathrm{~A}-\mathrm{H} 2 \mathrm{AB} \cdots \mathrm{O} 6_{\mathrm{w}}{ }^{\mathrm{iii}}$ & $0.85(4)$ & $2.08(4)$ & $2.918(4)$ & $169(4)$ & 1.07 & 2.4 \\
\hline $\mathrm{N} 1 \mathrm{~A}-\mathrm{H} 1 \mathrm{~A} \cdots \mathrm{O} 2 \mathrm{~B}^{\text {iv }}$ & $0.77(3)$ & $2.32(3)$ & 2.909 (3) & $134(3)$ & 1.07 & 2.7 \\
\hline $\mathrm{N} 1 \mathrm{~A}-\mathrm{H} 1 \mathrm{~A} \cdots \mathrm{O} 4 \mathrm{~B}{ }^{\text {iv }}$ & $0.77(3)$ & $2.60(3)$ & $3.355(4)$ & $167(3)$ & 1.02 & 2.9 \\
\hline $\mathrm{N} 3 \mathrm{~A}-\mathrm{H} 3 \mathrm{~A} \cdots \mathrm{O} 2 \mathrm{~A}$ & $0.76(3)$ & $2.08(3)$ & $2.835(3)$ & $175(3)$ & 0.95 & 6.1 \\
\hline $\mathrm{C} 6 \mathrm{~A}-\mathrm{H} 6 \mathrm{~A} \cdots \mathrm{O} 1 \mathrm{~B}{ }^{\mathrm{iv}}$ & 0.97 & 2.25 & $3.166(3)$ & 158.1 & 1.2 & 1.8 \\
\hline $\mathrm{N} 2 \mathrm{~B}-\mathrm{H} 2 \mathrm{BA} \cdots \mathrm{O} 3 \mathrm{~A}$ & $0.88(4)$ & $2.07(4)$ & $2.921(3)$ & $164(3)$ & 0.93 & 4.6 \\
\hline $\mathrm{N} 2 \mathrm{~B}-\mathrm{H} 2 \mathrm{BB} \cdots \mathrm{O} 3 \mathrm{~B}$ & $0.84(3)$ & $2.16(3)$ & $2.991(4)$ & $168(3)$ & 0.94 & 6.8 \\
\hline $\mathrm{N} 1 \mathrm{~B}-\mathrm{H} 1 \mathrm{~B} \cdots \mathrm{O} 4 \mathrm{~B}{ }^{\mathrm{iii}}$ & $0.80(3)$ & $2.28(3)$ & $3.040(4)$ & $159(3)$ & 1.07 & 2.7 \\
\hline $\mathrm{N} 3 \mathrm{~B}-\mathrm{H} 3 \mathrm{~B} \cdots \mathrm{O} 2 \mathrm{~B}$ & $0.85(3)$ & $1.93(3)$ & $2.764(3)$ & $168(3)$ & 0.92 & 7.7 \\
\hline $\mathrm{C} 6 \mathrm{~B}-\mathrm{H} 6 \mathrm{~B} \cdots \mathrm{O} 4 \mathrm{~A}^{\mathrm{iii}}$ & 0.97 & 2.39 & $3.336(3)$ & 165.1 & 1.21 & 1.7 \\
\hline $\mathrm{O}_{\mathrm{w}}-\mathrm{H} 61 \cdots \mathrm{O} 1 \mathrm{~A}$ & $0.90(1)$ & $1.99(1)$ & $2.880(3)$ & $172(4)$ & 1.00 & 6.1 \\
\hline $\mathrm{O}_{\mathrm{w}}-\mathrm{H} 62 \cdots \mathrm{O} 2 \mathrm{~A}$ & $0.89(1)$ & $2.01(2)$ & $2.838(3)$ & $153(4)$ & 0.98 & 6.8 \\
\hline
\end{tabular}

Symmetry codes: ${ }^{\mathrm{i}} x-1, y, z ;{ }^{\text {ii }} x, y, z+1 ;{ }^{\mathrm{iii}} x+1, y, z$; ${ }^{\text {iv }} x, y, z-1$.

5-Bromocytosinium sulfate, (IV), crystallizes in the monoclinic space group $P 2_{1} / c$, and the asymmetric unit consists of one $1 \mathrm{H}, 3 \mathrm{H}$-5-bromocytosinium cation protonated at the N3 atom, one sulfate anion, and one protonated water molecule of crystallization (Figure 4a). Short S-O bonds (1.458-1.483 (1) $\AA$ ) in the slightly distorted tetrahedral sulfate anion indicate the absence of $\mathrm{H}$ atoms and delocalization of negative charge between them. 


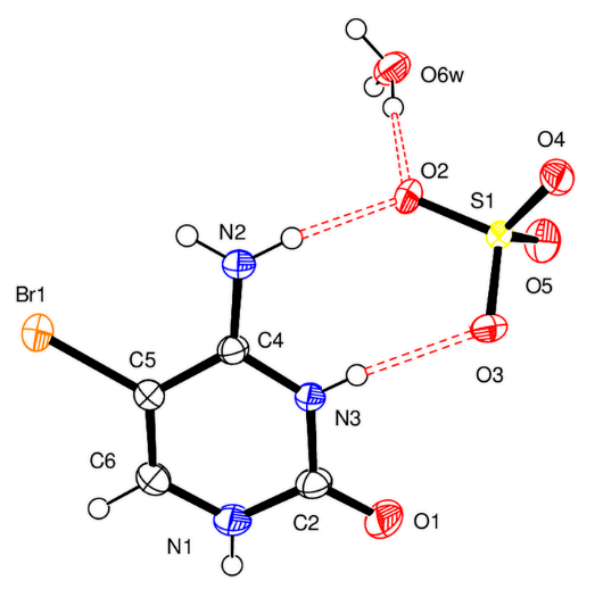

(a)

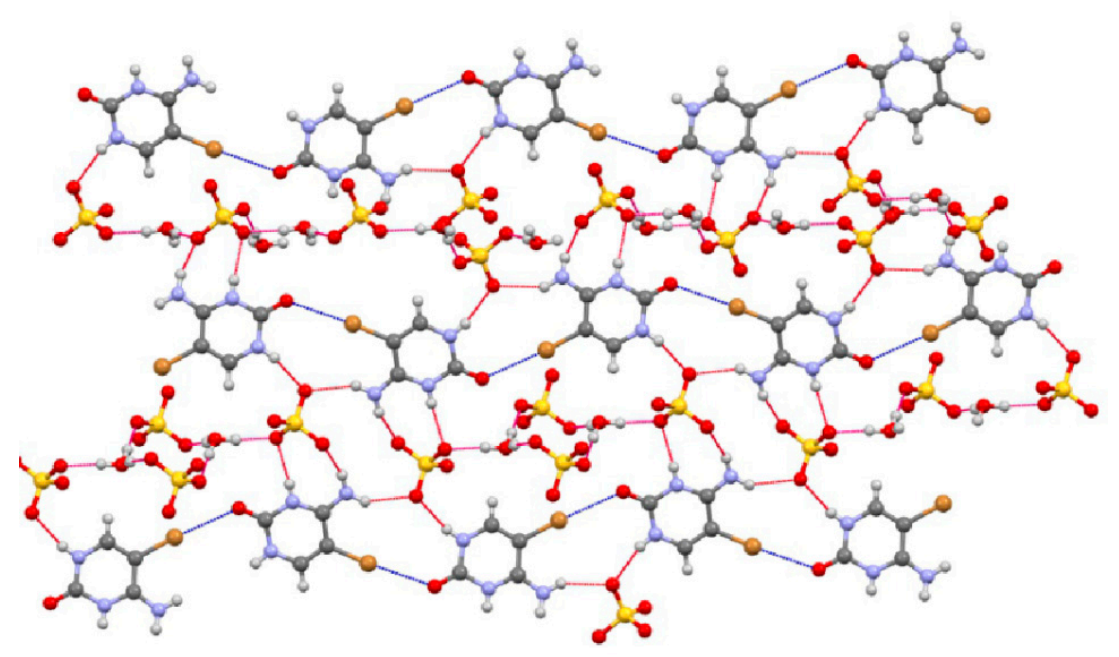

(b)

Figure 4. (a) The asymmetric unit of compound (IV), showing the adopted atom-numbering scheme. Displacement ellipsoids are at the $50 \%$ probability level. $\mathrm{H}$ atoms are shown as small spheres of arbitrary radii. Hydrogen bonding is shown as red dashed lines. (b) Part of the crystal structure of (IV). All atoms are shown as small spheres of arbitrary radii. Hydrogen bonding is shown as red dashed lines. Halogen bonding is shown as blue dashed lines.

In the crystal structure of compound (IV), the ionic components are joined together essentially by two kinds of short-contact interactions. The first one corresponds to $\mathrm{N}-\mathrm{H}^{\cdots} \mathrm{O}^{-}$ hydrogen bonds involving the oxygen atoms of the sulfate anion. These interactions were also localized by QTAIMS analysis and characterized by interaction energy between 5.0 and $7.0 \mathrm{kcal} / \mathrm{mol}$. The second type of interaction corresponds to an almost linear $\left(2.96 \AA, 175^{\circ}\right)$ and rather weak $\left(R_{\mathrm{XB}}=0.88\right) \mathrm{C}-\mathrm{Br} \cdots \mathrm{O}$ halogen bond involving bromine and carbonyl oxygen atoms of two adjacent 5-bromocytosinium cations, to give 1D zigzag chains (Figure $4 \mathrm{~b}$ ). The latter interaction has been indeed described by the topological analysis, and results in an interaction energy of $2.1 \mathrm{kcal} / \mathrm{mol}$ and a $\mathrm{G}(\mathrm{r}) / \mathrm{V}(\mathrm{r})$ value slightly larger than 1.20 . These chains are then connected by $\mathrm{N}-\mathrm{H}^{\cdots} \mathrm{O}^{-}$and $\mathrm{N}^{+}-\mathrm{H}^{\cdots} \mathrm{O}^{-}$hydrogen bonds with $1 \mathrm{D}$ chains formed by alternating sulfate and hydronium ions linked by two very strong $\mathrm{O}_{\mathrm{w}}-\mathrm{H}^{\cdots} \mathrm{O}^{-}$ interactions (Table 4) to form 2D layers. A short contact, C6-H6 $\cdots \mathrm{O}_{5}[3.169$ (2) $\AA$ ] has been confirmed by topological analysis showing a relatively low $\mathrm{E}_{\mathrm{int}}(1.7 \mathrm{kcal} / \mathrm{mol})$. The 2D layers, thus, formed are themselves linked into a three-dimensional network by the remaining very strong $\mathrm{O}_{\mathrm{w}}-\mathrm{H}^{\cdots} \mathrm{O}^{-}$hydrogen bond. More precisely, the analysis of this part of the structure reveals a peculiar interaction characterized by an $\mathrm{H}_{3} \mathrm{O}^{+}$moiety coordinating three sulfate anions, as also described in Table S10 in the Supporting Information, with strong HBs contacts whose interaction energies parallel the $-\mathrm{G}(\mathbf{r}) / \mathrm{V}(\mathbf{r})$ values of 0.90 , 0.59 and 0.69 . No relevant intermolecular $\mathrm{HBs}$ involving the $\mathrm{Br}$ atom were observed.

5-Bromocytosinium dihydrogen monophosphate, (V), crystallizes in the monoclinic space group $P 2_{1} / c$, and the asymmetric unit contains one $1 H, 3 H$-5-bromocytosinium cation protonated at the N3 atom and one dihydrogen monophosphate anion (Figure 5a). 
Table 4. Hydrogen-bond geometry $\left(\AA,^{\circ}\right)$ and topological analysis for compound (IV). $E_{\text {int }}$ is reported in kcal/mol. For additional details concerning QTAIMS results see Tables S8-S10 in the Supporting Information.

\begin{tabular}{|c|c|c|c|c|c|c|}
\hline$D-\mathbf{H} \cdots A$ & $D-\mathrm{H}$ & $\mathbf{H} \cdots A$ & $D \cdots A$ & $D-\mathbf{H} \cdots A$ & $-G(r) / V(r)$ & $\mathrm{E}_{\text {int }}$ \\
\hline $\mathrm{N} 2-\mathrm{H} 2 \mathrm{~A} \cdots \mathrm{O} 2$ & $0.86(3)$ & $2.08(3)$ & $2.883(2)$ & $155(3)$ & 0.91 & 4.8 \\
\hline $\mathrm{N} 2-\mathrm{H} 2 \mathrm{~B} \cdots \mathrm{O} 4^{\mathrm{i}}$ & $0.86(3)$ & $2.15(3)$ & $2.924(2)$ & $150(2)$ & 0.92 & 6.4 \\
\hline $\mathrm{N} 1-\mathrm{H} 1 \cdots \mathrm{O} 4^{\mathrm{ii}}$ & $0.82(3)$ & $2.11(3)$ & $2.877(2)$ & $154(3)$ & 0.93 & 5.0 \\
\hline $\mathrm{N} 3-\mathrm{H} 3 \cdots \mathrm{O} 3$ & $0.77(3)$ & $2.06(3)$ & $2.831(2)$ & $174(3)$ & 0.86 & 6.0 \\
\hline $\mathrm{O}_{\mathrm{w}}-\mathrm{H} 6 \mathrm{~A} \cdots \mathrm{O} 2^{\mathrm{i}}$ & $0.79(3)$ & $1.77(3)$ & $2.560(2)$ & $174(3)$ & 0.94 & 14.0 \\
\hline $\mathrm{O}_{\mathrm{w}}-\mathrm{H} 6 \mathrm{~B} \cdots \mathrm{O} 3^{\mathrm{iii}}$ & $0.89(3)$ & $1.70(3)$ & $2.588(2)$ & $173(3)$ & 0.79 & 17.3 \\
\hline $\mathrm{O}_{\mathrm{w}}-\mathrm{H} 6 \mathrm{C} \cdots \mathrm{O} 5^{\mathrm{iv}}$ & $0.93(3)$ & $1.58(4)$ & $2.504(2)$ & $177(3)$ & 0.55 & 25.6 \\
\hline
\end{tabular}

Symmetry codes: ${ }^{\text {i }}-x+1,-y+1,-z+2$; $^{\text {ii }}-x, y-1 / 2,-z+5 / 2 ;{ }^{\text {iii }}-x,-y+1,-z+2$; $^{\text {iv }} x, y, z-1$.

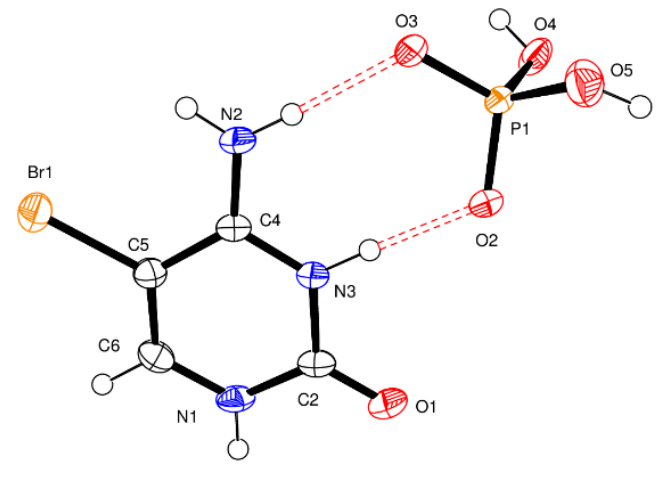

(a)

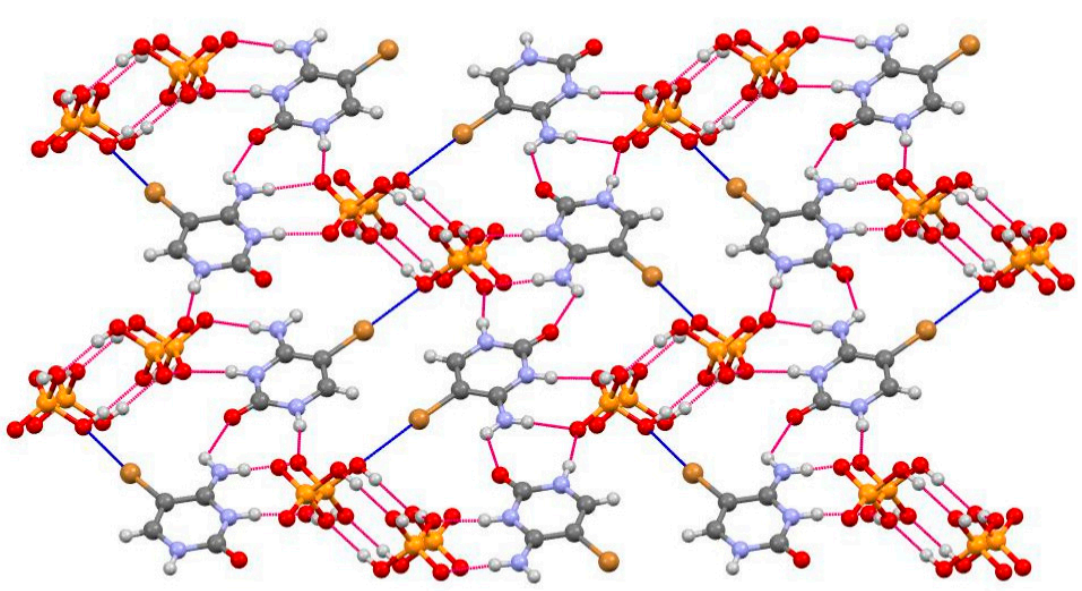

(b)

Figure 5. (a) The asymmetric unit of compound (V), showing the adopted atom-numbering scheme. Displacement ellipsoids are at the $50 \%$ probability level. $\mathrm{H}$ atoms are shown as small spheres of arbitrary radii. Hydrogen bonding is shown as red dashed lines. (b) Part of the crystal structure of (V). All atoms are shown as small spheres of arbitrary radii. Hydrogen bonding is shown as red dashed lines. Halogen bonding is shown as blue dashed lines.

The single deprotonation of the phosphoric acid is reflected in the bond distances involving the P1-O bonds in the slightly distorted tetrahedral phosphate group. There are two short P1-O bonds of 1.493 (2) and 1.503 (2) A to terminal atoms O2 and O3, respectively, and two longer bonds of 1.564 (2) and 1.569 (2) A to atoms O4 and O5, bearing H atoms. These values correlate well with those reported for dihydrogen monophosphate anion in the crystal structure of 6-methylisocytosinium dihydrogen monophosphate adduct [51]. The similarity of P1-O2 and P1-O3 bond distances suggests delocalization of negative charge between the two bonds.

The supramolecular structure of compound $(\mathbf{V})$ is based on a vast three-dimensional hydrogen-bonded network, which includes a combination of rather strong $\mathrm{O}-\mathrm{H} \cdots \mathrm{O}$ and $\mathrm{N}-\mathrm{H} \cdots \mathrm{O}$ hydrogen bonds (Figure $5 \mathrm{~b}$ ), as confirmed by the topological analysis. The hydrogen-bonding scheme involves all available donor/acceptor sites, but carbonyl O1, which remains partially unsaturated (Table 5). Within the cation chains, adjacent 5-bromocytosinium ions are linked head-to-tail through $\mathrm{N}-\mathrm{H} \cdots \mathrm{O}$ hydrogen bonds, so forming infinite chains. Each dihydrogen monophosphate ion participates in five N$\mathrm{H}^{\cdots} \mathrm{O}$ and $\mathrm{O}-\mathrm{H} \cdots \mathrm{O}$ hydrogen bonds with neighboring cations and anions as acceptor and in two $\mathrm{O}-\mathrm{H} \cdots \mathrm{O}$ hydrogen bonds with neighboring anions as a donor. Through these interactions, dihydrogen monophosphates form pairs, all showing a rather high $\mathrm{E}_{\mathrm{int}}$, of infinite chains cross-linked to cation chains. An approximately linear $\left(3.04 \AA, 171^{\circ}\right)$ and rather weak $\left(R_{\mathrm{XB}}=0.90\right) \mathrm{C}-\mathrm{Br} \cdots \mathrm{O}$ halogen bond involving the $\mathrm{O} 5$ oxygen atom connects pairs of 5-bromocytosinium and dihydrogen monophosphate ions. Similar XB interactions 
(3.00-3.01 $\left.\AA, 172-173^{\circ}\right)$ have been observed in the crystal structures of U2AF ${ }^{65}$-RNA complexes (U2AF $=\mathrm{U} 2$ auxiliary protein factor), where 5-bromouracil units are implicated in intramolecular $\mathrm{XBs}$ between $\mathrm{Br}$ atoms and $\mathrm{O}$ atoms belonging to nearby phosphate anions $[62,63]$. Topological analysis carried out on the latter contact has revealed interaction energy of $2.2 \mathrm{kcal} / \mathrm{mol}$ and a genuinely noncovalent character $(-\mathrm{G}(\mathrm{r}) / \mathrm{V}(\mathrm{r})>1.2)$.

Table 5. Hydrogen-bond geometry $\left(\AA^{\circ},{ }^{\circ}\right)$ and topological analysis for compound $(\mathbf{V})$. $\mathrm{E}_{\text {int }}$ is reported in $\mathrm{kcal} / \mathrm{mol}$. For additional details concerning QTAIMS results see Tables S11 and S12 in the Supporting Information.

\begin{tabular}{|c|c|c|c|c|c|c|}
\hline$D-\mathbf{H} \cdots A$ & $D-H$ & $\mathbf{H} \cdots A$ & $D \cdots A$ & $D-\mathbf{H} \cdots A$ & $-G(r) / V(r)$ & $E_{\text {int }}$ \\
\hline $\mathrm{N} 2-\mathrm{H} 2 \mathrm{~A} \cdots \mathrm{O} 3$ & 0.86 & 1.91 & $2.769(3)$ & 177.2 & 0.94 & 11.2 \\
\hline $\mathrm{N} 2-\mathrm{H} 2 \mathrm{~B} \cdots \mathrm{O} 1^{\mathrm{i}}$ & 0.86 & 2.30 & $2.818(3)$ & 118.9 & 1.16 & 3.4 \\
\hline $\mathrm{N} 1-\mathrm{H} 1 \cdots \mathrm{O} 33^{\mathrm{ii}}$ & $0.87(3)$ & $1.80(3)$ & $2.661(3)$ & $171(3)$ & 0.95 & 9.9 \\
\hline $\mathrm{N} 3-\mathrm{H} 3 \cdots \mathrm{O} 2$ & $0.92(3)$ & $1.81(3)$ & $2.720(3)$ & $175(3)$ & 0.94 & 9.5 \\
\hline $\mathrm{O} 4-\mathrm{H} 4 \cdots \mathrm{O} 2$ iii & $0.83(4)$ & $1.74(4)$ & $2.564(2)$ & $172(4)$ & 0.97 & 9.3 \\
\hline $\mathrm{O} 5-\mathrm{H} 5 \cdots \mathrm{O} 4$ iv & $0.87(5)$ & $1.87(5)$ & $2.722(3)$ & $170(5)$ & 0.97 & 10.2 \\
\hline
\end{tabular}

Symmetry codes: ${ }^{\mathrm{i}} x+1,-y+1 / 2, z-1 / 2{ }^{\text {ii }} x-1,-y+1 / 2, z+1 / 2 ;{ }^{\text {iii }} x+1, y, z ;{ }^{\text {iv }}-x+1,-y+1,-z$.

5-Bromocytosinium hydrogen oxalate, (VI), crystallizes in the monoclinic space group $P 2_{1} / c$, and the asymmetric unit consists of one $1 \mathrm{H}, 3 \mathrm{H}$-5-bromocytosinium cation protonated at the N3 atom, one hydrogen oxalate anion, and one water molecule of crystallization (Figure 6a). The semi-oxalate anion is almost planar, as the dihedral angle formed by the planes defined by the $\mathrm{CO}_{2} \mathrm{H}$ and $\mathrm{CO}_{2}{ }^{-}$non- $\mathrm{H}$ atoms is $5.2(4)^{\circ}$. Bond distances around atom C7 [1.248-1.250 (3) $\AA$ ] are typical of a carboxylate group, and the differences between them of 0.002 (3) $\AA$ indicates delocalization of the negative charge between the two O atoms. Bond distances around atom C8 (1.209(4) and 1.300 (4) $\AA$ ) are consistent with the presence of a carboxylic acid group.

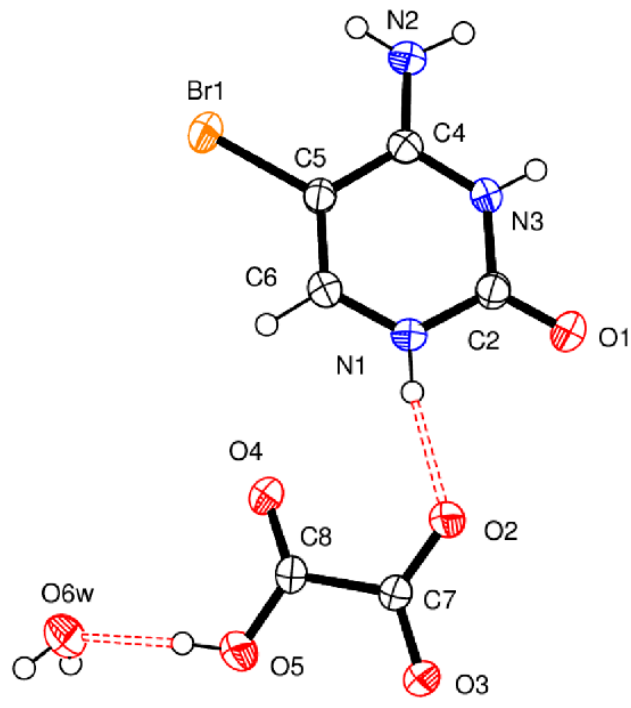

(a)

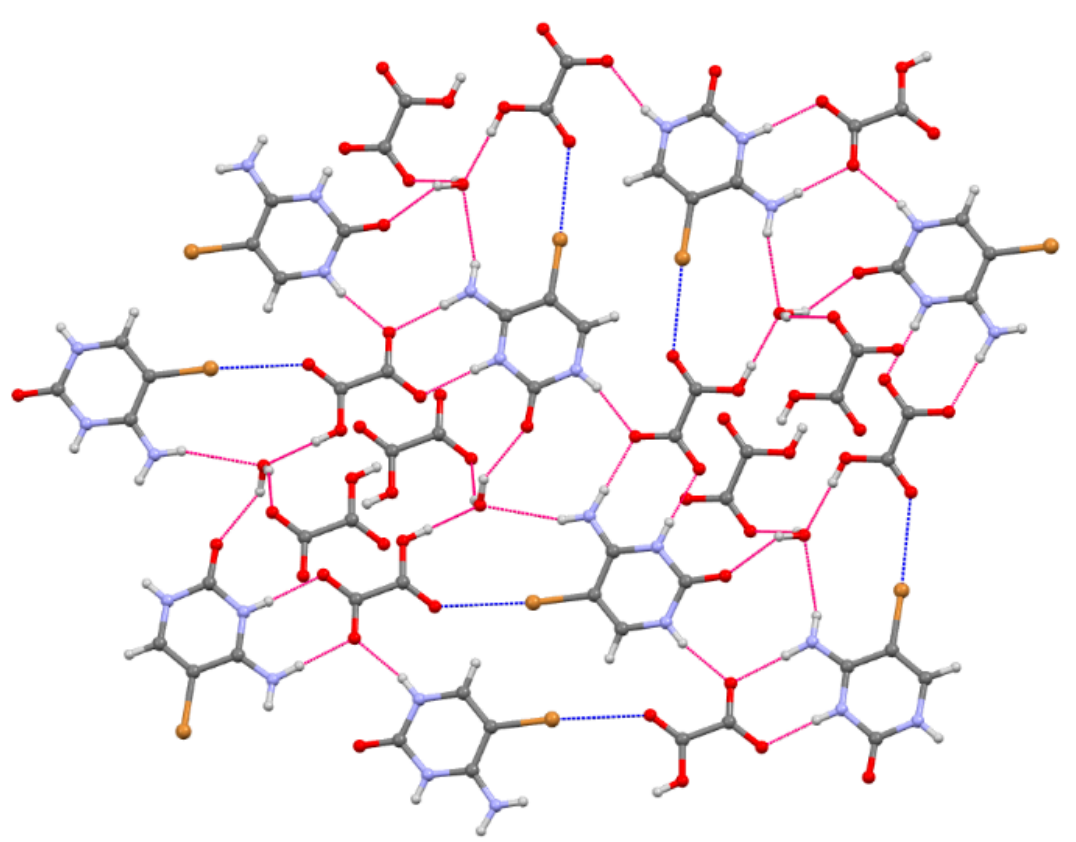

(b)

Figure 6. (a) The asymmetric unit of compound (VI), showing the adopted atom-numbering scheme. Displacement ellipsoids are at the $50 \%$ probability level. $\mathrm{H}$ atoms are shown as small spheres of arbitrary radii. Hydrogen bonding is shown as red dashed lines. (b) Part of the crystal structure of (VI). All atoms are shown as small spheres of arbitrary radii. Hydrogen bonding is shown as red dashed lines. Halogen bonding is shown as blue dashed lines. 
The crystal structure of compound (VI) is dominated by different structurally significant hydrogen bonds, formed by neutral and charged $\mathrm{N}-\mathrm{H} \cdots \mathrm{O}$ and $\mathrm{O}-\mathrm{H} \cdots \mathrm{O}$ interactions (Figure $6 \mathrm{~b}$ ). Two semi-oxalate anions are engaged in hydrogen bonds with two 5-bromocytosinium cations and two water molecules, forming an $\mathrm{R}_{6}^{6}(22)$ hydrogen-bonded ring. This subunit is then linked into a two-dimensional network by multiple hydrogen bonds, whose $\mathrm{E}_{\text {int }}$ is relatively strong by QTAIMS analysis, and a weak $\mathrm{C}-\mathrm{Br} \cdots \mathrm{O}$ halogen bond $\left(2.97 \AA, 166^{\circ}, R_{\mathrm{XB}}=0.88\right)$ between 5-bromocytosinium cations and hydrogen oxalate anions. This latter interaction is characterized by a relatively high $-\mathrm{G}(\mathrm{r}) / \mathrm{V}(\mathrm{r})$ value (1.20) and a value on $\mathrm{E}_{\mathrm{int}}$ of $2.1 \mathrm{kcal} / \mathrm{mol}$. As previously mentioned, water molecules play an important role in the cohesion of the crystal structure, as they maximize $\mathrm{HB}$ interactions with all potential donors and acceptors utilized. They form one $\mathrm{N}-\mathrm{H}^{\cdots} \mathrm{O}_{\mathrm{w}}$ and one $\mathrm{O}-$ $\mathrm{H} \cdots \mathrm{O}_{\mathrm{w}}$ hydrogen bonds connecting one 5-bromocytosinium cation and one semi-oxalate anion as donors, and two $\mathrm{O}_{\mathrm{w}}-\mathrm{H} \cdots$ O hydrogen bonds connecting one 5-bromocytosinium cation and one semi-oxalate anion as acceptors (Table 6). No relevant intermolecular HBs involving the $\mathrm{Br}$ atom were observed.

Table 6. Hydrogen-bond geometry $\left(\AA{ }^{\circ}{ }^{\circ}\right)$ and topological analysis for compound (VI). $E_{\text {int }}$ is reported in kcal/mol. For additional details concerning QTAIMS results see Tables S13 and S14 in the Supporting Information.

\begin{tabular}{|c|c|c|c|c|c|c|}
\hline$D-\mathbf{H} \cdots A$ & $D-H$ & $\mathbf{H} \cdots A$ & $D \cdots A$ & $D-\mathbf{H} \cdots A$ & $-G(r) / V(r)$ & $\mathrm{E}_{\mathrm{int}}$ \\
\hline $\mathrm{N} 2-\mathrm{H} 21 \cdots \mathrm{O} 2^{\mathrm{i}}$ & $0.89(4)$ & $1.89(4)$ & $2.770(3)$ & $171(4)$ & 0.91 & 7.3 \\
\hline $\mathrm{N} 2-\mathrm{H} 22 \cdots \mathrm{O} 6_{\mathrm{w}} \mathrm{ii}$ & $0.85(4)$ & $2.57(4)$ & $3.389(4)$ & $162(3)$ & 1.18 & 2.0 \\
\hline $\mathrm{N} 1-\mathrm{H} 1 \cdots \mathrm{O} 2$ & $0.83(4)$ & $1.90(4)$ & $2.710(3)$ & $167(4)$ & 0.92 & 7.3 \\
\hline $\mathrm{N} 3-\mathrm{H} 3 \cdots 3{ }^{i}$ & $0.82(4)$ & $1.86(4)$ & $2.673(3)$ & $173(4)$ & 0.91 & 8.3 \\
\hline $\mathrm{O} 5-\mathrm{H} 5 \cdots \mathrm{O} 6_{\mathrm{w}}$ & $0.83(5)$ & $1.86(5)$ & $2.674(4)$ & $169(5)$ & 1.00 & 9.0 \\
\hline $\mathrm{O}_{\mathrm{w}}-\mathrm{H} 61 \cdots \mathrm{O} 1^{\mathrm{iii}}$ & $0.84(7)$ & $2.10(7)$ & $2.852(4)$ & $149(6)$ & 1.03 & 6.0 \\
\hline $\mathrm{O}_{\mathrm{w}}-\mathrm{H} 62 \cdots \mathrm{O} 3^{\text {iv }}$ & $0.73(5)$ & $2.18(5)$ & $2.849(4)$ & $155(5)$ & 0.95 & 7.0 \\
\hline
\end{tabular}

Symmetry codes: ${ }^{\mathrm{i}} x+1,-y+1 / 2, z-1 / 2$; $^{\mathrm{ii}}-x+1,-y,-z+1 ;{ }^{\mathrm{iii}}-x, y-1 / 2,-z+3 / 2$; $^{\mathrm{iv}}-x,-y,-z+2$.

\subsection{Full Interaction Maps Analysis}

Analysis of full interaction maps (FIM) has been carried out to evaluate the probability of occurring hydrogen and halogen bonds around specific functional groups, and to reveal if the most likely combination of $\mathrm{HB}$ and $\mathrm{XB}$ donors and acceptors are satisfied in the crystal structure of compounds (I-VI). By applying the FIM tool implemented in the graphical user interface of the Mercury program (CSD version 2020.2.0, Materials module), this methodology generates, for the different functional groups of a molecule, 3D scatterplots through CSD contact searches with a chosen probe. These scatterplots are then converted into scaled density maps, which are combined for the whole molecule, resulting in different contour surfaces. Plotting contour surfaces shows the probability of an interaction at a certain grid-point with respect to random chance [64,65]. 3D visualization of how the probability of $\mathrm{HB}$ and $\mathrm{XB}$ interactions affects the overall packing in the crystal structure of compound (VI), which has been selected as a representative example, as depicted in Figure 7. FIMs for compounds (I-V) can be found in Figure S1 in the Supporting Information. 


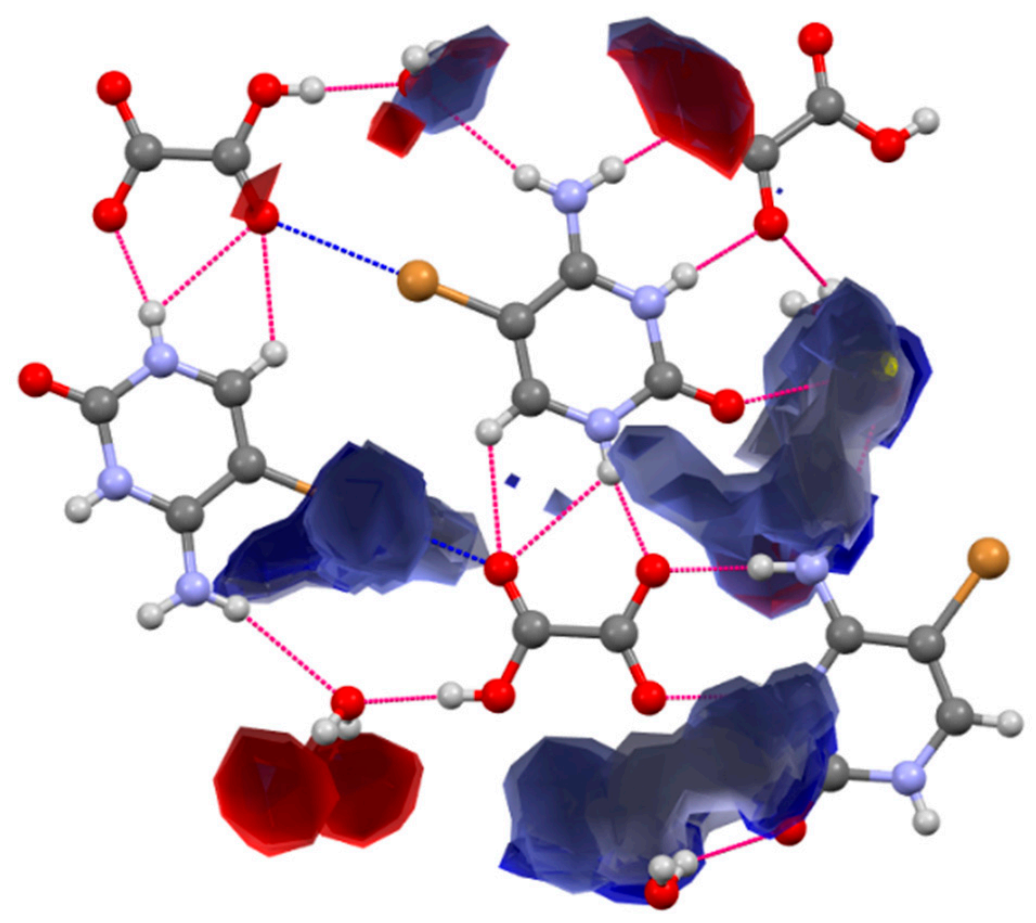

Figure 7. Visualization of the full interaction map calculated around the content of the asymmetric unit for compound (VI). Region of HB acceptor and donor likelihood are shown in red and blue, respectively. Acceptor peaks for halogen bonds are shown in violet. Hydrogen bonding is shown as red dashed lines. Halogen bonding is shown as blue dashed lines.

FIMs were calculated around the content of the asymmetric unit of each compound. The set of probe functional groups used as proxies of acceptors and donors of hydrogen bonds comprises oxygen atoms of carbonyl and water molecules (red), and uncharged and charged $\mathrm{N}-\mathrm{H}$ (blue), respectively. $\mathrm{C}-\mathrm{Br}$ (violet) was used as a probe of halogen bonds. Visual inspection of the interaction maps shows that the most expected positions of $\mathrm{HB}$ acceptors and donors and $\mathrm{XB}$ acceptors correlate well with the previously discussed packing arrangements of compounds (I-VI). In particular, all the FIMs show the strongest donor peak pointing at the $\mathrm{O} 1$ atom of the carbonyl group, which is the most expected hydrogen-bond acceptor. The presence of weak acceptor peaks (violet) along the $\mathrm{C}-\mathrm{Br}$ bond axis for the 5-bromocytosinium cations indicates the moderate propensity of these ions to form halogen bonds.

\subsection{Hirshfeld Surface Analysis}

The intermolecular interactions were analyzed using the Hirshfeld surface (HS), which maps the normalized contact distance, $d_{\text {norm }}$, on the pro-molecule surface, and its respective 2D fingerprint plots. From the HS, both the previously noted hydrogen and halogen bond may be estimated qualitatively from the intensity of the red spots corresponding to the distance between the interaction sites $d_{\text {norm }}$ shorter than the sum of the vdW radii of interacting atoms. The intensity of the red spot varies from high, due to strong hydrogen bond, to feeble, due to the close contact by $\mathrm{C}=\mathrm{O} \cdots \mathrm{Br}$. The HS of compound (VI), which has been selected as a representative example, as depicted in Figure 8. HS for compounds $(\mathbf{I}-\mathbf{V})$ can be found in Figure S8 in the Supporting Information. 


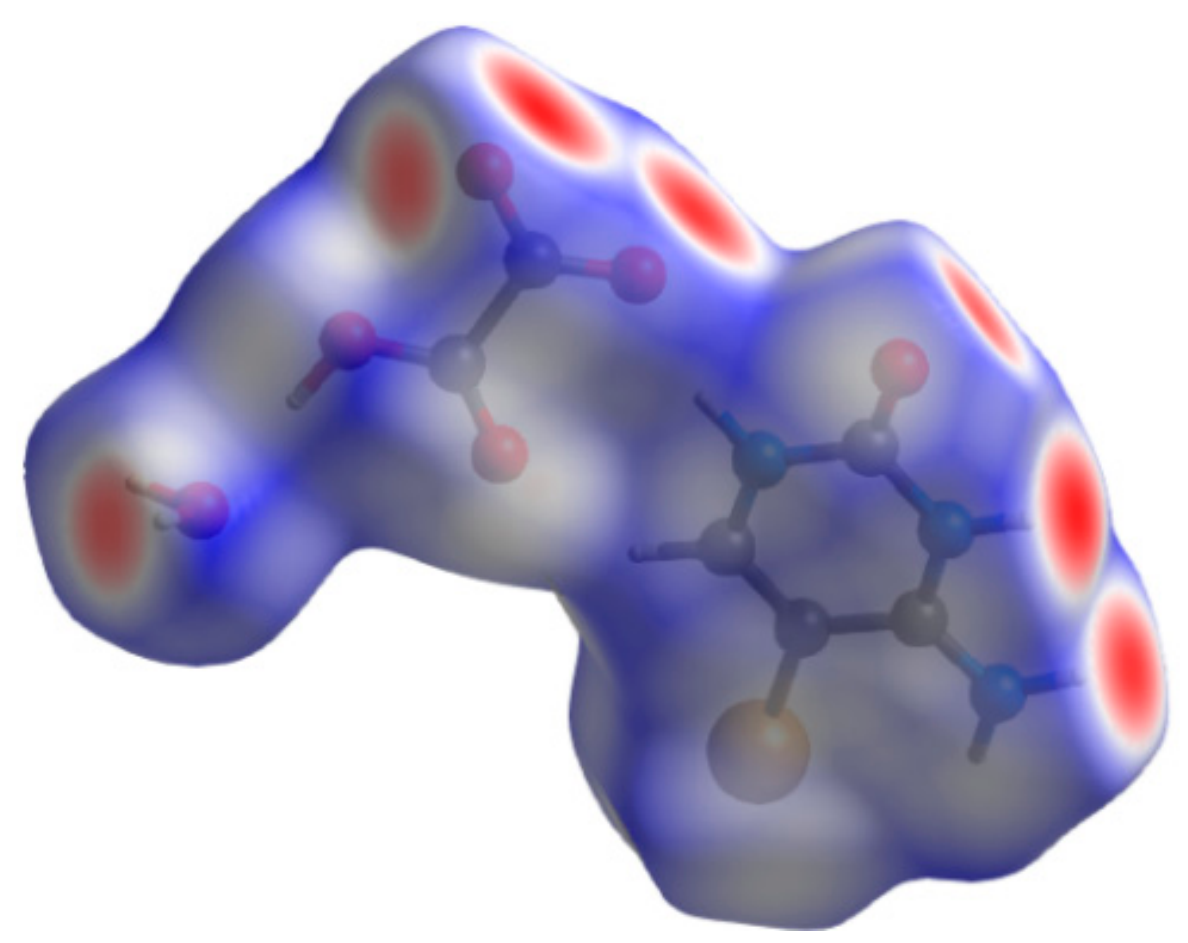

Figure 8. Visualization of the Hirshfeld surface for compound (VI) mapped on $d_{\text {norm }}$. The color range is in arbitrary units; color scale: -0.7300 (red) 0.9540 a.u. (blue).

Figure 9 represents the relative contribution of the various atom $\cdots$ atom contacts observed for all the investigated crystal structures from the analysis of decomposed 2Dfingerprint plots (see Figures S2-S7 in the Supporting Information). In all cases, supramolecular arrangements are determined primarily by interatomic contacts involving oxygen and hydrogen atoms, which vary from $15.7 \%$ in compound (I) to $59.0 \%$ in compound (IV) and confirms that intermolecular neutral and charged hydrogen bonds play a fundamental role in the crystal packing. HS of compounds (III-VI) shows the maximum amount of $\mathrm{O} \cdots \mathrm{H} / \mathrm{H} \cdots \mathrm{O}$ interactions compared to structures (I and II). These interactions account for $37.1-59.0 \%$ of the surface, in accordance with the presence of oxygenated anions. The $\mathrm{H}$ ‥ H contacts, representing van der Waals interactions, comprise $7.6-16.0 \%$ of the total intermolecular contacts. The lower proportion of the $\mathrm{Br} \cdots \mathrm{H} / \mathrm{H} \cdots \mathrm{Br}, \mathrm{C} \cdots \mathrm{H} / \mathrm{H} \cdot$ . $\mathrm{C}$ and $\mathrm{Br} \cdots \mathrm{O} / \mathrm{O} \cdots \mathrm{Br}$ makes up 5.9-32.0, 3.2-9.8 and 2.0-8.9\%, respectively, of the Hirshfeld surface. Lower abundances are found for $\mathrm{N} \cdots \mathrm{H} / \mathrm{H} \cdots \mathrm{N}(0.8-7.4 \%), \mathrm{Br} \cdots \mathrm{Br}$ $(0.7-7.1 \%), \mathrm{O} \cdots \mathrm{C} / \mathrm{C} \cdots \mathrm{O}(0.5-6.9 \%), \mathrm{O} \cdots \mathrm{N} / \mathrm{N} \cdots \mathrm{O}(0.3-5.2 \%), \mathrm{Br} \cdots \mathrm{C} / \mathrm{C} \cdots \mathrm{Br}$ $(0.9-4.6 \%)$ and $\mathrm{Br} \cdots \mathrm{N} / \mathrm{N} \cdots \mathrm{Br}(1.2-4.6 \%) . \mathrm{Cl} \cdots \mathrm{H} / \mathrm{H} \cdots \mathrm{Cl}(11.9 \%), \mathrm{C} \cdots \mathrm{Cl} / \mathrm{Cl}$. $\cdots \mathrm{C}(8.0 \%), \mathrm{N} \cdots \mathrm{Cl} / \mathrm{Cl} \cdots \mathrm{N}(3.8 \%)$ and $\mathrm{Br} \cdots \mathrm{Cl} / \mathrm{Cl} \cdots \mathrm{Br}(2.1 \%)$ are observed only for compound (I). Other intermolecular contacts contribute less than $4 \%$ to the Hirshfeld surface mapping. 
(VI)

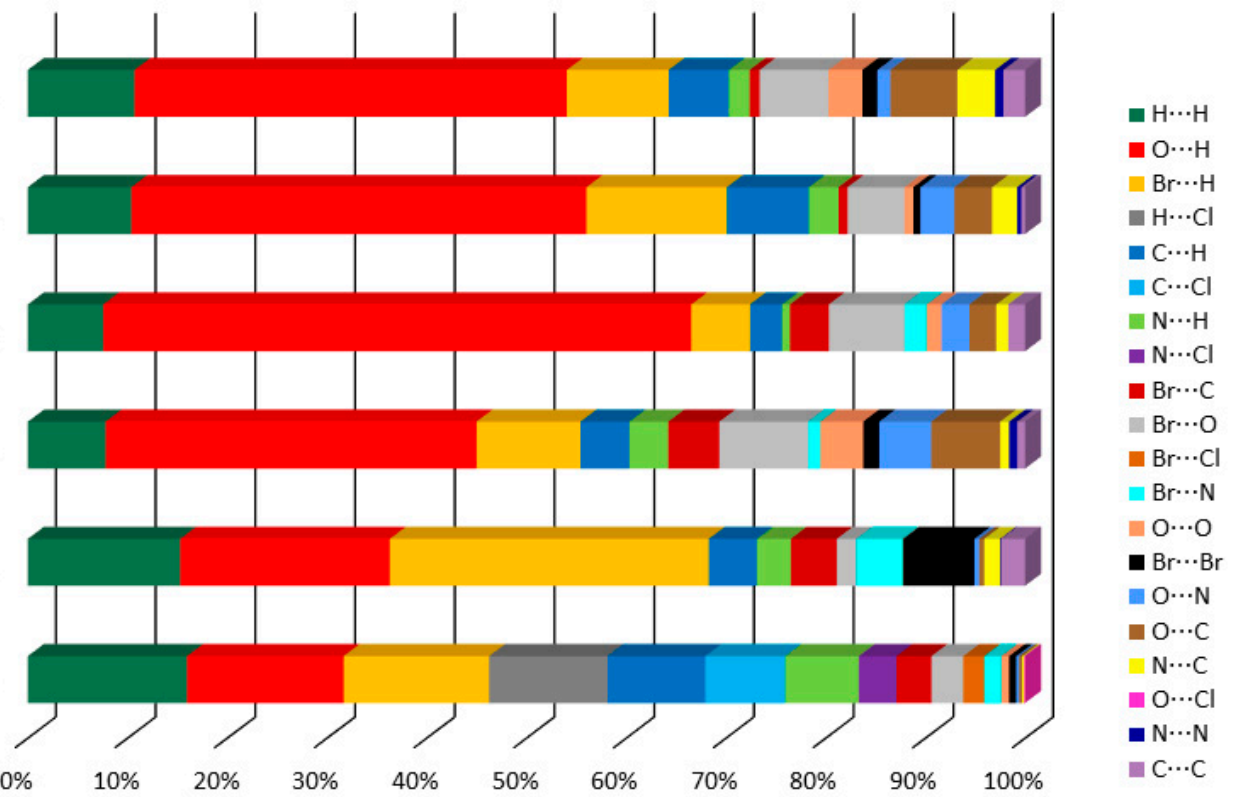

Figure 9. The relative contributions of different intermolecular contacts to the Hirshfeld surface area observed in the crystal packing of compounds (I-VI).

\subsection{Crystallographic Evidence of Proton Transfer in Compounds (I-VI)}

Careful inspection of difference Fourier maps, calculated without the H3 hydrogen atom, gives clear evidence of protonation of compounds (I-VI) at the N3 ring position. Figure 10 shows the difference Fourier map for compound (II), which has been selected as a representative example, highlighting the electron density maximum corresponding to the position of the hydrogen atom in the neighborhood of N3 atom for pyrimidinium ring. Difference Fourier maps for compounds (I) and (III-VI) can be found in Figure S9 in the Supporting Information.

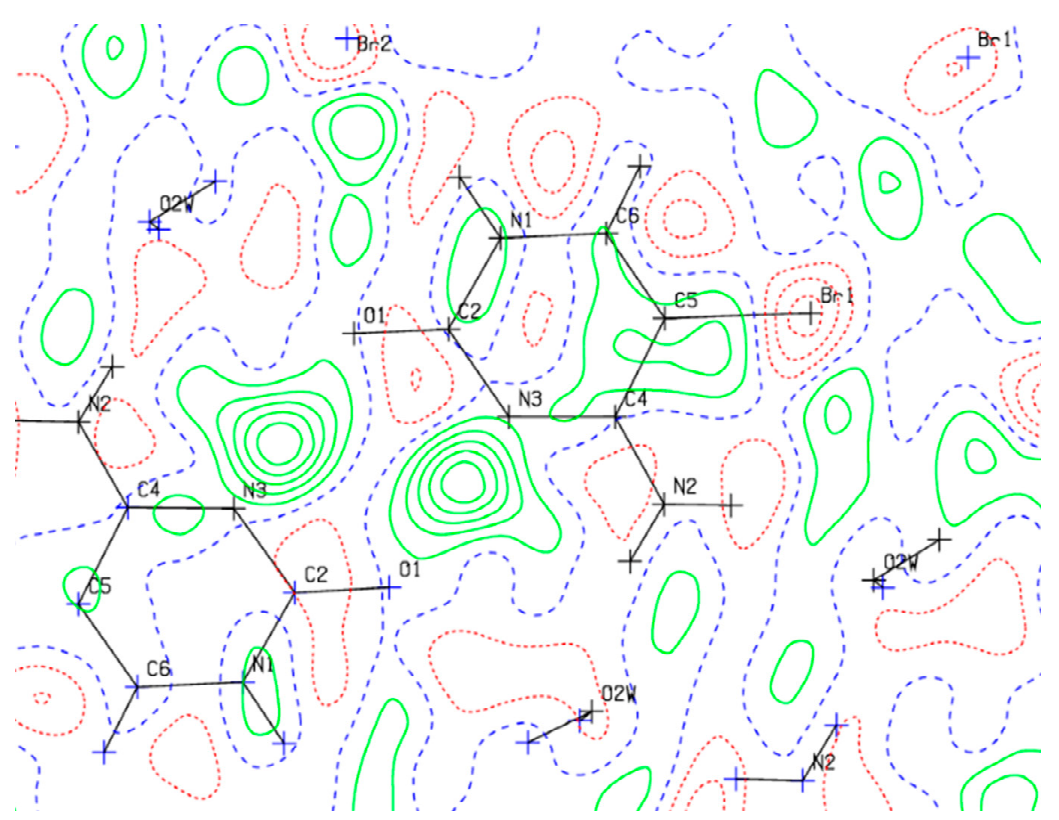

Figure 10. Visualization of the difference Fourier map through $\mathrm{C} 2, \mathrm{~N} 3$, and C4 atoms of compound (II), revealing the hydrogen atom at the N3 ring position. Electron density is in the range -0.20 (blue line)- $0.60 \mathrm{e} / \AA^{3}$ (green line). 
The effect of N3-protonation on the ring molecular geometries is revealed by inspection of Table 7. Comparison of selected geometrical parameters of compounds containing the planar 5-bromocytosinium cation shows that the independent molecules have almost equivalent geometry, as the differences among the corresponding bond distances and angles are in the range $0.019-0.040$ (13) $\AA$ and $2.0-3.7(10)^{\circ}$, respectively (hereafter the standard uncertainties of the differences have been calculated as the square root of the sum of the squares of the estimated standard deviations of geometrical parameters reported in Table 7, [66]). The N3 protonation reflects in the C4-N3-C2 bond angle, which is significantly larger than the corresponding one, $120.2^{\circ}$ (6), for neutral 5-bromocytosine, BRCYTS [25], by 4.5-6.5 (8) ${ }^{\circ}$. This difference is fully consistent with the VSEPR theory, according to which the steric requirements of the lone pair on deprotonated aza nitrogen atom implies a wider region than the covalent bond $\mathrm{N}^{+}-\mathrm{H}$. As a result, the protonation of the endocyclic N3 imino atom increases the C4-N3-C2 bond angle with respect to that on the unprotonated N3 atom [50].

Table 7. Selected geometric parameters of 5-bromocytosinium cation for compounds (I-VI), HABKEA ${ }^{a}$ and NUZKEY $^{b}$.

\begin{tabular}{|c|c|c|c|c|c|c|c|c|c|}
\hline \multicolumn{10}{|l|}{ Bond distances $(\AA)$} \\
\hline & & (I) & & & (II) & & (III) & & \\
\hline & & Mol A & Mol B & Mol C & & & Mol A & Mol B & Mol C \\
\hline $\mathrm{Br} 1-\mathrm{C} 5$ & $1.855(7)$ & $1.870(8)$ & $1.855(7)$ & $1.880(7)$ & $1.884(3)$ & $1.871(3)$ & $1.874(2)$ & $1.870(3)$ & $1.867(3)$ \\
\hline $\mathrm{O} 1-\mathrm{C} 2$ & $1.215(8)$ & $1.202(9)$ & $1.211(8)$ & $1.204(9)$ & $1.219(4)$ & $1.215(3)$ & $1.213(3)$ & $1.211(3)$ & $1.202(3)$ \\
\hline $\mathrm{N} 2-\mathrm{C} 4$ & $1.314(9)$ & $1.310(9)$ & $1.304(9)$ & 1.307 (10) & $1.293(4)$ & $1.306(4)$ & $1.305(3)$ & $1.298(4)$ & $1.300(4)$ \\
\hline$N 1-\mathrm{C} 6$ & $1.336(9)$ & $1.348(10)$ & $1.351(9)$ & $1.353(9)$ & $1.360(5)$ & $1.363(4)$ & $1.355(3)$ & $1.360(4)$ & $1.351(4)$ \\
\hline $\mathrm{N} 1-\mathrm{C} 2$ & $1.362(9)$ & $1.378(10)$ & $1.358(9)$ & $1.382(9)$ & $1.362(4)$ & $1.368(4)$ & $1.372(4)$ & $1.363(3)$ & $1.368(4)$ \\
\hline $\mathrm{C} 2-\mathrm{N} 3$ & $1.381(9)$ & $1.388(10)$ & $1.381(9)$ & $1.385(10)$ & $1.372(4)$ & $1.376(4)$ & $1.369(4)$ & $1.375(3)$ & $1.380(4)$ \\
\hline N3-C4 & $1.356(8)$ & $1.353(10)$ & $1.348(9)$ & $1.345(9)$ & $1.360(4)$ & $1.348(3)$ & $1.359(3)$ & $1.341(3)$ & $1.356(4)$ \\
\hline $\mathrm{C} 4-\mathrm{C} 5$ & $1.420(9)$ & $1.419(10)$ & $1.441(9)$ & $1.422(10)$ & $1.426(4)$ & $1.424(4)$ & $1.417(3)$ & $1.432(3)$ & $1.420(4)$ \\
\hline \multirow[t]{3}{*}{$\mathrm{C} 5-\mathrm{C} 6$} & $1.354(10)$ & $1.323(10)$ & $1.350(10)$ & $1.324(10)$ & 1.333 (5) & $1.335(4)$ & $1.347(4)$ & $1.343(4)$ & $1.342(4)$ \\
\hline & (IV) & (V) & (VI) & НАВКЕА & & NUZKEY & & & \\
\hline & & & & & Mol A & Mol B & Mol C & & \\
\hline $\mathrm{Br} 1-\mathrm{C} 5$ & $1.874(2)$ & $1.876(2)$ & $1.871(3)$ & $1.871(4)$ & $1.867(5)$ & $1.859(4)$ & 1.887 (7) & & \\
\hline $\mathrm{O} 1-\mathrm{C} 2$ & $1.211(2)$ & $1.214(3)$ & $1.217(3)$ & 1.205 (5) & $1.201(8)$ & $1.219(8)$ & $1.206(9)$ & & \\
\hline$N 2-C 4$ & $1.304(2)$ & $1.305(3)$ & 1.309 (4) & 1.309 (5) & $1.305(7)$ & $1.298(8)$ & $1.293(9)$ & & \\
\hline$N 1-C 6$ & $1.357(3)$ & $1.348(3)$ & $1.354(3)$ & $1.354(6)$ & $1.331(8)$ & $1.357(8)$ & $1.371(11)$ & & \\
\hline$N 1-C 2$ & $1.368(3)$ & $1.371(3)$ & $1.369(4)$ & $1.368(7)$ & $1.364(8)$ & $1.348(8)$ & $1.361(9)$ & & \\
\hline $\mathrm{C} 2-\mathrm{N} 3$ & $1.384(2)$ & $1.382(3)$ & $1.385(4)$ & $1.378(5)$ & $1.375(7)$ & $1.384(8)$ & $1.385(11)$ & & \\
\hline $\mathrm{N} 3-\mathrm{C} 4$ & $1.352(2)$ & $1.348(3)$ & $1.355(3)$ & $1.353(5)$ & $1.355(6)$ & $1.348(8)$ & $1.341(7)$ & & \\
\hline $\mathrm{C} 4-\mathrm{C} 5$ & $1.430(2)$ & $1.424(3)$ & $1.430(4)$ & $1.419(7)$ & $1.423(7)$ & $1.430(8)$ & $1.416(9)$ & & \\
\hline $\mathrm{C} 5-\mathrm{C} 6$ & $1.351(3)$ & $1.350(3)$ & $1.353(4)$ & $1.349(5)$ & $1.352(8)$ & $1.351(8)$ & $1.331(11)$ & & \\
\hline \multicolumn{10}{|l|}{ Bond angles $\left({ }^{\circ}\right)$} \\
\hline & & (I) & & & (II) & & (III) & & \\
\hline & & Mol A & Mol B & Mol C & & & Mol A & Mol B & Mol C \\
\hline $\mathrm{C} 6-\mathrm{N} 1-\mathrm{C} 2$ & $123.5(6)$ & $123.1(6)$ & $123.9(6)$ & $123.5(6)$ & $122.6(3)$ & $122.9(3)$ & $123.0(3)$ & $123.0(3)$ & $123.8(3)$ \\
\hline $\mathrm{O} 1-\mathrm{C} 2-\mathrm{N} 1$ & $123.8(7)$ & $125.0(7)$ & $124.0(7)$ & $123.8(7)$ & $122.7(3)$ & $123.3(3)$ & $122.6(3)$ & $123.5(3)$ & 124.0 (3) \\
\hline $\mathrm{O} 1-\mathrm{C} 2-\mathrm{N} 3$ & $122.2(6)$ & $122.5(7)$ & $122.1(6)$ & $123.4(7)$ & $122.4(3)$ & $122.1(3)$ & $123.2(3)$ & $122.1(2)$ & $122.3(3)$ \\
\hline $\mathrm{N} 1-\mathrm{C} 2-\mathrm{N} 3$ & $114.0(6)$ & $112.5(7)$ & $114.0(6)$ & $112.8(6)$ & $115.0(3)$ & $114.6(3)$ & $114.2(2)$ & $114.4(3)$ & $113.7(3)$ \\
\hline $\mathrm{C} 4-\mathrm{N} 3-\mathrm{C} 2$ & $124.7(6)$ & $126.7(6)$ & $125.8(6)$ & $126.5(6)$ & $125.3(3)$ & $125.4(3)$ & $126.4(2)$ & $126.4(2)$ & $125.8(2)$ \\
\hline $\mathrm{N} 2-\mathrm{C} 4-\mathrm{N} 3$ & $117.9(6)$ & $118.9(7)$ & $119.3(6)$ & $119.1(7)$ & $119.5(3)$ & $119.2(3)$ & $118.9(2)$ & $119.6(2)$ & $118.4(3)$ \\
\hline $\mathrm{N} 2-\mathrm{C} 4-\mathrm{C} 5$ & $123.9(6)$ & $124.4(7)$ & $123.5(6)$ & $124.7(7)$ & $124.1(3)$ & $123.9(3)$ & $125.2(2)$ & $124.2(3)$ & $124.9(3)$ \\
\hline $\mathrm{N} 3-\mathrm{C} 4-\mathrm{C} 5$ & $118.2(6)$ & $116.6(6)$ & $117.2(6)$ & $116.3(7)$ & $116.3(3)$ & $116.9(3)$ & $115.9(2)$ & $116.2(2)$ & $116.8(3)$ \\
\hline $\mathrm{C} 6-\mathrm{C} 5-\mathrm{C} 4$ & $116.6(7)$ & $118.1(7)$ & $117.3(7)$ & $119.3(7)$ & $118.9(3)$ & $119.1(3)$ & $119.4(2)$ & $119.0(3)$ & $118.7(3)$ \\
\hline $\mathrm{C} 6-\mathrm{C} 5-\mathrm{Br} 1$ & $120.9(5)$ & $122.3(6)$ & $121.7(5)$ & $121.3(6)$ & $122.2(2)$ & $120.9(2)$ & $120.6(2)$ & $120.5(2)$ & $121.4(2)$ \\
\hline $\mathrm{C} 4-\mathrm{C} 5-\mathrm{Br} 1$ & $122.5(5)$ & $119.6(5)$ & $121.0(5)$ & $119.1(6)$ & $118.8(2)$ & $120.0(2)$ & $120.0(2)$ & $120.5(2)$ & $119.9(2)$ \\
\hline \multirow[t]{3}{*}{$\mathrm{N} 1-\mathrm{C} 6-\mathrm{C} 5$} & $122.6(7)$ & $123.0(7)$ & $121.8(6)$ & $121.4(7)$ & $121.6(3)$ & $121.0(3)$ & $121.0(3)$ & $121.0(3)$ & $121.2(3)$ \\
\hline & (IV) & (V) & (VI) & НАВКЕА & & NUZKEY & & & \\
\hline & & & & & Mol A & Mol B & Mol C & & \\
\hline $\mathrm{C} 6-\mathrm{N} 1-\mathrm{C} 2$ & $123.5(2)$ & $122.8(2)$ & $122.9(2)$ & $123.1(4)$ & $124.7(5)$ & $123.1(5)$ & $122.5(6)$ & & \\
\hline $\mathrm{O} 1-\mathrm{C} 2-\mathrm{N} 1$ & $124.1(2)$ & $123.4(2)$ & $122.9(3)$ & $123.6(4)$ & $125.9(6)$ & $125.5(6)$ & $123.5(7)$ & & \\
\hline $\mathrm{O} 1-\mathrm{C} 2-\mathrm{N} 3$ & $121.9(2)$ & $121.6(2)$ & $122.0(3)$ & $122.5(4)$ & $120.9(5)$ & $119.7(6)$ & $121.9(6)$ & & \\
\hline $\mathrm{N} 1-\mathrm{C} 2-\mathrm{N} 3$ & $114.0(2)$ & $114.9(2)$ & $115.1(2)$ & $113.9(3)$ & $113.1(5)$ & $114.8(5)$ & $114.6(6)$ & & \\
\hline $\mathrm{C} 4-\mathrm{N} 3-\mathrm{C} 2$ & $125.8(2)$ & $124.8(2)$ & $124.7(2)$ & $126.3(4)$ & $126.0(5)$ & $125.7(5)$ & $125.8(6)$ & & \\
\hline $\mathrm{N} 2-\mathrm{C} 4-\mathrm{N} 3$ & $119.2(2)$ & $119.0(2)$ & $119.4(2)$ & $118.8(4)$ & $119.1(5)$ & $119.4(5)$ & $120.0(6)$ & & \\
\hline $\mathrm{N} 2-\mathrm{C} 4-\mathrm{C} 5$ & $123.7(2)$ & $123.5(2)$ & $123.2(3)$ & $124.7(4)$ & $124.2(5)$ & $124.3(5)$ & $123.6(6)$ & & \\
\hline $\mathrm{N} 3-\mathrm{C} 4-\mathrm{C} 5$ & $117.1(2)$ & $117.4(2)$ & $117.3(2)$ & $116.5(4)$ & $116.7(5)$ & $116.3(5)$ & $116.4(6)$ & & \\
\hline $\mathrm{C} 6-\mathrm{C} 5-\mathrm{C} 4$ & $118.1(2)$ & $118.4(2)$ & $118.4(2)$ & $118.6(4)$ & $118.0(5)$ & $118.5(5)$ & $120.0(6)$ & & \\
\hline $\mathrm{C} 6-\mathrm{C} 5-\mathrm{Br} 1$ & $121.8(1)$ & $121.8(2)$ & $122.4(2)$ & $120.9(3)$ & $122.5(4)$ & $122.1(4)$ & $120.1(5)$ & & \\
\hline $\mathrm{C} 4-\mathrm{C} 5-\mathrm{Br} 1$ & $120.0(1)$ & $119.8(2)$ & $119.2(2)$ & $120.6(3)$ & $119.5(4)$ & $119.4(4)$ & $119.9(5)$ & & \\
\hline $\mathrm{N} 1-\mathrm{C} 6-\mathrm{C} 5$ & $121.5(2)$ & $121.4(2)$ & $121.4(2)$ & $121.5(4)$ & $121.1(5)$ & $121.2(5)$ & $120.7(6)$ & & \\
\hline
\end{tabular}


Due to protonation at the N3 atom, some degree of charge delocalization is expected, and can be revealed by checking the molecular geometry of the N3-C4(-N2)-C5 fragment of 5-bromocytosinium cations against that of the neutral 5-bromocytosine. In passing from BRCYTS to protonated compounds (I-VI), the most relevant distortions in the molecular geometry of the fragment can be summarized as follows: (i) A decrease of the N2-C4 bond distances by $0.037-0.058$ (9) $\AA$ ); (ii) an increase of the N3-C4 bond distances by $0.004-0.023$ (6) $\AA$; (iii) a decrease of the N3-C4-C5 bond angle by $2.0-4.3$ (7) ${ }^{\circ}$ (in BRCYTS the corresponding bond distances and angle are $1.351,1.337 \AA$ and $120.2^{\circ}$, respectively). Thus, the observed structural changes, although to the limits of statistical relevance, taken together suggest that protonation at the N3 ring position causes a redistribution of $\pi$-electron density in the cation, increasing $\pi$-donation from the amino group to the pyrimidinium ring (canonical form (B) in Figure 11). Planar arrangement of the fragment (the maximum deviation from the least-squares plane being 0.004 (1) $\AA$ for the N2 atom of the amino group) is another evidence of the proposed $\pi$-delocalization. Raising $\pi$-donation from the amino group to the pyrimidine ring favors, as observed in the above-reported discussion of crystal packing, the $\mathrm{N}_{(\text {amino) }}-\mathrm{H} \cdots X$ hydrogen bonds in compounds (I-VI) to become progressively stronger, as the positive charge which resides on the nitrogen atom increases the polarity of the $\mathrm{N}-\mathrm{H}$ bonds $[67,68]$.

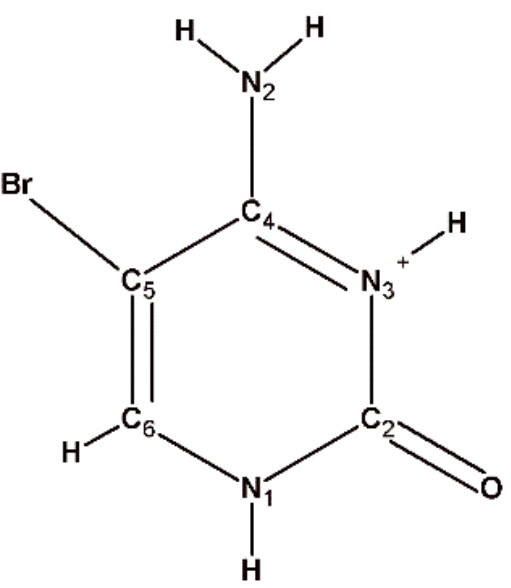

(A)

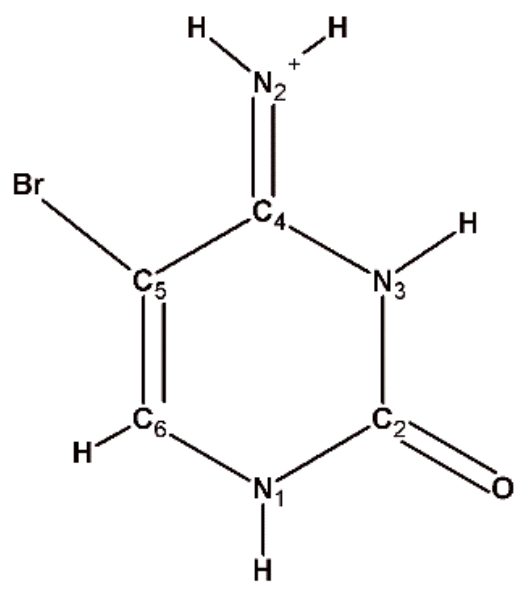

(B)

Figure 11. Two possible canonical forms (A,B) for 5-bromocytosinium cations in compounds (I-VI).

\section{Materials and Methods}

\subsection{Supramolecular Synthesis}

5-Bromocytosine, oxalic and phosphoric acids were purchased from Aldrich (99\% purity) and subjected to further purification by successive sublimation under reduced pressure. Mineral acids were used as received without any further purification. For each compound, $0.1 \mathrm{mmol}$ of 5-bromocytosine was dissolved in water. The solutions were warmed over a heating magnetic stirrer hotplate at $60{ }^{\circ} \mathrm{C}$ with continuous stirring for $12 \mathrm{~h}$ under reflux. For compounds (I-IV), water solutions of the diluted mineral acids were then added, while stirring, dropwise until pH reached 2. For compounds (V) and (VI), equimolar distilled water solutions of phosphoric and oxalic acids were then added while stirring. The resulting solutions were allowed to cool slowly to room temperature and then filtered. After ca one week, plate-shaped colorless crystals were obtained by slow evaporation of the solvent at room temperature.

\subsection{Single Crystal Structure Analysis}

The single crystal structures were examined on an Xcalibur S CCD diffractometer (graphite-monochromated Mo K $\alpha$ radiation, $\lambda=0.710689 \AA$, Oxford Diffraction, Oxford, UK) at room temperature using the CrysAlisPro software package (Rigaku Oxford Diffrac- 
tion, Yarnton, England, 2018) [69]. The crystal structures were solved by direct methods using SIR2004 [70]. All the nonhydrogen atoms were refined anisotropically by the full-matrix least-squares method based on squared structure factors $\left(F^{2}\right)$ using SHELXL-2014/7 [71], within the WinGX system [72]. All $\mathrm{H}$ atoms were found from difference Fourier, but for final refinement, all C-bound $\mathrm{H}$ atoms were placed in calculated positions, with $\mathrm{C}-\mathrm{H}=0.97 \AA$ and $U_{\text {iso }}(\mathrm{H})=1.2 \mathrm{U}_{\text {eq }}$ of the parent $\mathrm{C}$ atom and treated as riding on the adjacent atoms. Positional and isotropic thermal parameters of $\mathrm{H}$ atoms of the heteroatoms were freely refined in all but compounds (I), (II), (IV), and (V). For these compounds, free refinement of positional coordinates of atoms of the amino groups resulted in an unsatisfactory wide range of $\mathrm{N}-\mathrm{H}$ distances, and consequently, these bond lengths were restrained to $0.86 \AA$. The molecular and packing diagrams were prepared using the Mercury 3.9 program package [73]. Difference Fourier maps were computed using Platon. CCDC 2073401-2073406 contains the supplementary crystallographic data for this paper. These data can be obtained free of charge via http:/ / www.ccdc.cam.ac.uk/conts/ retrieving.html (accessed on 26 March 2021) or from the CCDC, 12 Union Road, Cambridge CB2 1EZ, UK; Fax: +44 1223 336033; E-mail: deposit@ccdc.cam.ac.uk).

The details of crystal data, data collection, and structure refinement can be found in Table S16 of the Supporting Information.

\subsection{Computational Methods}

The Hirshfeld surfaces (HS) and their associated 2D fingerprint plots were computed using Crystal Explorer17 (University of Western Australia: Crawley, AU, Australia [74]).

Quantum chemical calculations were performed on a series of selected clusters constructed from the asymmetric unit of each compound and extended to properly account for the hydrogen and halogen bonds located based on the X-ray structural analysis.

All the calculations were carried out-adopting the following protocol for each cluster. First, the structure, once extracted from the crystal structure, was partially optimized by keeping frozen the relative roto-translations between the different moieties (obviously in the case of monoatomic ions, only the relative distance was constrained). In this case, only the bond distances and the intramolecular bond angles were allowed to relax. This procedure was carried out using Hartree-Fock calculations with the $6-31+G(d)$ basis set. It is important to remark that further test-optimizations in the framework of Density Functional Theory, using the wB97XD functional, including the dispersion correction [75] with the same basis set, carried out on small clusters, did not significantly improve the final outcome, essentially because of the intramoieties constraints, and hence, not utilized on larger clusters. Subsequently, QTAIMS analysis was conducted on single points (SP) calculations at the $w B 97 X D / 6-31+G(d)$ level of theory on the optimized structures. The software Gaussian 09 [76] was utilized for the optimization and SP calculations, whereas the software Multiwfn, version 3.7 [77] was adopted for the QTAIMS analysis. All the optimized structures and QTAIMS additional details not reported in this study can be found in the Supplementary Information. Cartesian coordinates, coordinates and index of the bond CP for all the cluster adopted in this work can be found in Table S15 of the Supporting Information.

\section{Conclusions}

In summary, six novel organic salts of 5-bromocytosine were prepared and fully characterized by single crystal X-ray diffraction. In addition to X-ray analyses, the topological analysis based on the QM and subsequent QTAIMS calculations have confirmed that all the experimentally identified short-range interactions correspond to bond $\mathrm{CP}$ (i.e., critical points with rank and signature equal to 3 and -1 , respectively) at which interaction energies are sensibly larger, and in some cases much larger, than the thermal energies.

At variance with pure 5-bromocytosine, in which halogen bonding interactions are not present, and the molecular assembly is dominated by conventional hydrogen bonds, all but (II) compounds show weak to moderately strong $\mathrm{C}-\mathrm{Br} \cdots \mathrm{O}$ interactions $(\mathrm{Br} \cdots \mathrm{O}$ 
distances are from $4 \%$ to $24 \%$ shorter than the sum of $R_{\mathrm{vdW}}$ and the calculated interaction energies are in the range of $\approx 1.0-4.0 \mathrm{kcal} \mathrm{mol}^{-1}$ ).

Although halogen bonding plays an appreciable role, and in the absence of base stacking interactions between consecutive 5-bromocytosinium ions, in all six compounds, the crystal packing is mainly stabilized by conventional hydrogen bonds. Most of these HB interactions are due to strong hydrogen-bond donor $\mathrm{N}-\mathrm{H}, \mathrm{N}^{+}-\mathrm{H}$ and $\mathrm{O}-\mathrm{H}$ sites in the 5-bromocytosinium cation, in the counterions, and in the water and $\mathrm{H}_{3} \mathrm{O}^{+}$molecules.

In compounds (I), (III), and (IV), $\mathrm{C}-\mathrm{Br} \cdots \mathrm{O}$ halogen bonds involve the carbonyl oxygen atoms of adjacent 5-bromocytosinium ions as XB acceptors, while in (V) and (VI), oxygen atoms of the counterions (dihydrogen monophosphate and hydrogen oxalate, respectively) act as $\mathrm{XB}$ acceptors.

In compound (III), showing two weak "lateral" halogen interactions $\left(R_{X \mathrm{~B}}=0.94\right.$ and 0.90, respectively), the $\mathrm{C}-\mathrm{Br} \cdots \mathrm{O}$ angles, $\theta_{1}$, are $150.3(2)^{\circ}$ and $157.0(2)^{\circ}$, and the $\mathrm{C}=\mathrm{O} \cdots \mathrm{Br}$ angles, $\theta_{2}$, are $150.9(2)^{\circ}$ and $157.6(2)^{\circ}$ (Figure 12). Similar values for the corresponding $\theta_{1}$ and $\theta_{2}$ angles have been found in 5-chlorouracil/melamine (2:1), 5bromouracil/melamine (2:1) and 5-bromo-1-methyl uracil/melamine (2:1) complexes [54]. These values indicate significant deviations from the average value observed for $\theta_{2}, 113^{\circ}$, in 5-halonucleobases [9]. They could suggest that strong linear XB with carbonyl oxygen atoms favors a halogen $\cdots \mathrm{O}=\mathrm{C}$ angle close to $120^{\circ}$, corresponding to the optimum approach of the halogen atoms to the $\mathrm{sp}^{2}$ orbitals on carbonyl oxygen atoms. Conversely, in the presence of weak $\mathrm{XB}, \theta_{1}$ deviates from linearity, and $\theta_{2}$ becomes more sensitive to additional interactions competing for the $\mathrm{O}$ acceptor site.

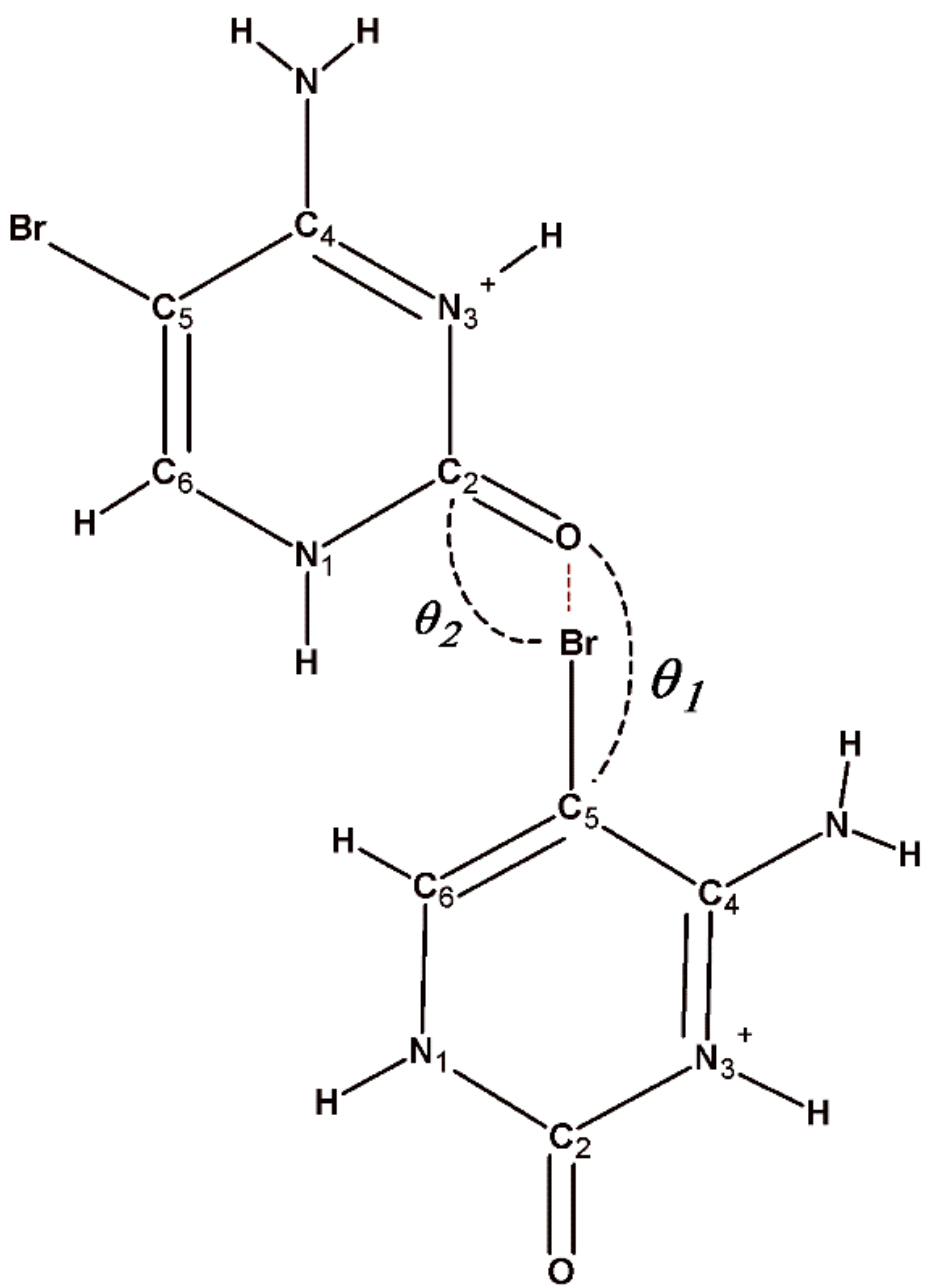

Figure 12. Schematic showing angles defining the approach of the $l p$ acceptor towards the $l p$ donor $\left(\theta_{1}\right)$ and the $l p$ donor towards the $l p$ acceptor $\left(\theta_{2}\right)$. 
Such experimental/theoretical study may provide useful information on the stability of the DNA model containing protonated halonucleobases-in which the pyrimidinium $\mathrm{N}^{+}-\mathrm{H}$ moiety would act as an electron-withdrawing group to activate the $\mathrm{C}-\mathrm{Br}$ moiety as $\mathrm{XB}$ donor. Indeed, although electrostatic characteristics of halonucleobases are different from those of DNA (due to the presence of the phosphate backbone), our results suggest that halogenated nucleic acids could use the carbonyl oxygen atom of 5-bromocytosine, besides oxygen atoms of the phosphate group $[3,6,13,14]$, as favorable negative site able to interact with the positive $\sigma$-hole on halogen atoms.

Supplementary Materials: The following are available online. Figure S1: full interaction maps for compounds (I-V); Figures S2-S7: Decomposed two-dimensional fingerprint plots; Figure S8: Hirshfeld surfaces for compounds (I-V); Figure S9: Difference Fourier maps for compounds (I) and (III-VI); Tables S1-S14: geometrical details, and related bond-CP index for the short-contact pair-interactions emerged from structural analysis; Table S15: Cartesian coordinates of all the clusters utilized in the work and Cartesian coordinates of the corresponding bond-CP. Table S16: Crystal data, data collection, and refinement for compounds (I-VI).

Author Contributions: Conceptualization, G.P.; methodology, M.A. and G.P.; software, M.A. and G.P.; investigation, G.T.B. and G.P.; writing—original draft preparation, M.A. and G.P.; writingreview and editing, M.A. and G.P. All authors have read and agreed to the published version of the manuscript.

Funding: This research received no external funding.

Institutional Review Board Statement: Not applicable.

Informed Consent Statement: Not applicable.

Data Availability Statement: The data presented in this study are openly available in the Supplementary Information file.

Acknowledgments: M.A. would like to thank CINECA (Italy) for an Iscra-C project.

Conflicts of Interest: The authors declare no conflict of interest.

Sample Availability: Samples of all compounds are available from the authors.

\section{References}

1. Bartosik, K.; Debiec, K.; Czarnecka, A.; Sochacka, E.; Leszczynska, G. Synthesis of Nucleobase-Modified RNA Oligonu-cleotides by Post-Synthetic Approach. Molecules 2020, 25, 3344. [CrossRef]

2. Del Prado, A.; González-Rodríguez, D.; Wu, Y.-L. Functional Systems Derived from Nucleobase Self-assembly. ChemistryOpen 2020, 9, 409-430. [CrossRef] [PubMed]

3. Voth, A.R.; Hays, F.A.; Ho, P.S. Directing macromolecular conformation through halogen bonds. Proc. Natl. Acad. Sci. USA 2007, 104, 6188-6193. [CrossRef] [PubMed]

4. Metrangolo, P.; Resnati, G. Halogen Versus Hydrogen. Science 2008, 321, 918-919. [CrossRef] [PubMed]

5. Parker, A.J.; Stewart, J.; Donald, K.J.; Parish, C.A. Halogen Bonding in DNA Base Pairs. J. Am. Chem. Soc. 2012, 134, 5165-5172. [CrossRef] [PubMed]

6. Kolář, M.H.; Tabarrini, O. Halogen Bonding in Nucleic Acid Complexes. J. Med. Chem. 2017, 60, 8681-8690. [CrossRef] [PubMed]

7. Rowe, R.K.; Ho, P.S. Relationships between hydrogen bonds and halogen bonds in biological systems. Acta Crystallogr. Sect. B Struct. Sci. Cryst. Eng. Mater. 2017, 73, 255-264. [CrossRef] [PubMed]

8. Cavallo, G.; Metrangolo, P.; Milani, R.; Pilati, T.; Priimagi, A.; Resnati, G.; Terraneo, G. The Halogen Bond. Chem. Rev. 2016, 116, 2478-2601. [CrossRef]

9. Auffinger, P.; Hays, F.A.; Westhof, E.; Ho, P.S. Halogen bonds in biological molecules. Proc. Natl. Acad. Sci. USA 2004, 101, 16789-16794. [CrossRef]

10. Portalone, K.R.H.M.T.J.O.M.G.; Moilanen, J.O.; Tuononen, H.M.; Rissanen, K. Role of Weak Hydrogen Bonds and Halogen Bonds in 5-Halo-1,3-dimethyluracils and Their Cocrystals-A Combined Experimental and Computational Study. Cryst. Growth Des. 2016, 16, 2631-2639. [CrossRef]

11. Bondi, A. van der Waals Volumes and Radii. J. Phys. Chem. 1964, 68, 441-451. [CrossRef]

12. Ennifar, E.; Bernacchi, S.; Wolff, P.; Dumas, P. Influence of C-5 halogenation of uridines on hairpin versus duplex RNA folding. RNA 2007, 13, 1445-1452. [CrossRef] [PubMed]

13. Xu, L.; Sang, P.; Zou, J.-W.; Xu, M.-B.; Li, X.-M.; Yu, Q.-S. Evaluation of nucleotide C-Br $\cdots \mathrm{O}-\mathrm{P}$ contacts from ONIOM calculations: Theoretical insight into halogen bonding in nucleic acids. Chem. Phys. Lett. 2011, 509, 175-180. [CrossRef] 
14. de las Nieves Pinã, M.; Frontera, A.; Bauzà, A. Quantifying intramolecular Halogen Bonds in Nucleic Acids: A combined PDB and theoretical study. ACS Chem. Biol. 2020, 15, 1942-1948. [CrossRef] [PubMed]

15. Valinluck, V.; Sowers, L.C. Inflammation-Mediated Cytosine Damage: A Mechanistic Link between Inflammation and the Epigenetic Alterations in Human Cancers: Figure 1. Cancer Res. 2007, 67, 5583-5586. [CrossRef] [PubMed]

16. Seiberling, K.A.; Church, C.A.; Herring, J.L.; Sowers, L.C. Epigenetics of chronic rhinosinusitis and the role of the eosinophil. Int. Forum Allergy Rhinol. 2011, 2, 80-84. [CrossRef]

17. Zdrowowicz, M.; Wityk, P.; Michalska, B.; Rak, J. 5-Bromo-2'-deoxycytidine-a potential DNA photosensitizer. Org. Biomol. Chem. 2016, 14, 9312-9321. [CrossRef]

18. Liu, M.; Yang, L.; Deng, W.; Su, M.; Wang, C.; Lin, S.-B.; Kan, L.-S.; Bai, C. Effect of Selective Substitution of 5-Bromocytosine on Conformation of DNA Triple Helices. J. Biomol. Struct. Dyn. 1998, 15, 895-903. [CrossRef]

19. Yang, L.; Liu, M.; Deng, W.; Wang, C.; Bai, C.; Kan, L.-S. Influence of 5-bromodeoxycytosine substitution on triplex DNA stability and conformation. Biophys. Chem. 1999, 76, 25-34. [CrossRef]

20. Wilcox, J.L.; Ahluwalia, A.K.; Bevilacqua, P.C. Charged Nucleobases and Their Potential for RNA Catalysis. Acc. Chem. Res. 2011, 44, 1270-1279. [CrossRef]

21. Kumar, P.; Cabaj, M.K.; Pazio, A.; Dominiak, P.M. Protonated nucleobases are not fully ionized in their chloride salt crystals and form metastable base pairs further stabilized by the surrounding anions. IUCrJ 2018, 5, 449-469. [CrossRef] [PubMed]

22. Gehring, K.; Leroy, J.-L.; Guéron, M. A tetrameric DNA structure with protonated cytosine-cytosine base pairs. Nat. Cell Biol. 1993, 363, 561-565. [CrossRef] [PubMed]

23. Assi, H.A.; Garavís, M.; González, C.; Damha, M.J. i-Motif DNA: Structural features and significance to cell biology. Nucleic Acids Res. 2018, 46, 8038-8056. [CrossRef] [PubMed]

24. Zeraati, M.; Langley, D.B.; Schofield, P.; Moye, A.L.; Rouet, R.; Hughes, W.E.; Bryan, T.M.; Dinger, M.E.; Christ, D. I-motif DNA structures are formed in the nuclei of human cells. Nat. Chem. 2018, 10, 631-637. [CrossRef] [PubMed]

25. Sengupta, P.; Bose, D.; Chatterjee, S. The Molecular Tête-à-Tête between G-Quadruplexes and the i-motif in the Human Genome. ChemBioChem 2021, 22, 1517-1537. [CrossRef] [PubMed]

26. Yang, B.; Wu, R.R.; Rodgers, M.T. Base-Pairing Energies of Proton-Bound Dimers and Proton Affinities of 1-Methyl-5Halocytosines: Implications for the Effects of Halogenation on the Stability of the DNA i-Motif. J. Am. Soc. Mass Spectrom. 2015, 26, 1469-1482. [CrossRef]

27. Groom, C.R.; Bruno, I.J.; Lightfoot, M.P.; Ward, S.C. The Cambridge Structural Database. Acta Crystallogr. Sect. B Struct. Sci. Cryst. Eng. Mater. 2016, 72, 171-179. [CrossRef]

28. Ohki, M.; Takénaka, A.; Shimanouchi, H.; Sasada, Y. Complexes between Nucleotide Base and Amino Acid. II. Crystal Structure of 5-Bromocytosine: N-Tosyl-L-glutamic Acid. Bull. Chem. Soc. Jpn. 1976, 49, 3493-3497. [CrossRef]

29. Ohki, M.; Takénaka, A.; Shimanouchi, H.; Sasada, Y. Complexes between Nucleotide Base and Amino Acid. III. Crystal Structure of 5-Bromocytosine:Phthaloyl-DL-glutamic Acid Complex Hemihydrate. Bull. Chem. Soc. Jpn. 1977, 50, 90-96. [CrossRef]

30. Kato, M.; Takénaka, A.; Sasada, Y. Crystal Structure of 5-Bromocytosine. Bull. Chem. Soc. Jpn. 1979, 52, 49-51. [CrossRef]

31. Casellato, U.; Ettorre, R.; Graziani, R. Bis(5-bromocytosinium) tetrachloropalladate(II). Acta Crystallogr. Sect. C Cryst. Struct. Commun. 1993, 49, 956-957. [CrossRef]

32. Valle, G.; Ettorre, R. Crystal structure of tris(5-bromocytosinium) hexachloroplatìnate(IV) chloride monohydrate, [C4H5BrON3] 3[PtCl6]Cl H2O. Z. für Kristallogr.-New Crystal Structures 1998, 213, 327-328. [CrossRef]

33. Podolyan, Y.; Gorb, L.; Leszczynski, J. Ab Initio Study of the Prototropic Tautomerism of Cytosine and Guanine and Their Contribution to Spontaneous Point Mutations. Int. J. Mol. Sci. 2003, 4, 410-421. [CrossRef]

34. Alcolea Palafox, M. Computational chemistry applied to vibrational spectroscopy: A tool for characterization of nucleic acid bases and some of their 5-substituted derivatives. Phys. Sci. Rev. 2017, 2, 118-151.

35. Singh, V.; Fedeles, B.I.; Essigmann, J.M. Role of tautomerism in RNA biochemistry. RNA 2015, 21, 1-13. [CrossRef] [PubMed]

36. Wempen, I.; Fox, J.J. Spectrometric Studies of Nucleic Acid Derivatives and Related Compounds. VI. On the Structure of Certain 5- and 6-Halogenouracils and -cytosines. J. Am. Chem. Soc. 1964, 86, 2474-2477. [CrossRef]

37. Childs, S.L.; Stahly, A.G.P.; Park, A. The Salt-Cocrystal Continuum: The Influence of Crystal Structure on Ionization State. Mol. Pharm. 2007, 4, 323-338. [CrossRef]

38. Desiraju, G.R. A Bond by Any Other Name. Angew. Chem. Int. Ed. 2011, 50, 52-59. [CrossRef]

39. Molčanov, K.; Kojić-Prodić, B. Salts and co-crystals of chloranilic acid with organic bases: Is it possible to predict a salt formation? CrystEngComm. 2009, 12, 925-939. [CrossRef]

40. Saunders, L.K.; Nowell, H.; Hatcher, L.E.; Shepherd, H.J.; Teat, S.J.; Allan, D.R.; Raithby, P.R.; Wilson, C.C. Ex-ploring short strong hydrogen bonds engineered in organic acid molecular crystals for temperature dependent proton mi-gration behaviour using single crystal synchrotron X-ray diffraction (SCSXRD). CrystEngComm 2019, 21, 5249-5260. [CrossRef]

41. Spackman, M.A.; Jayatilaka, D. Hirshfeld surface analysis. CrystEngComm 2009, 11, 19-32. [CrossRef]

42. Bader, R.F.W. A quantum theory of molecular structure and its applications. Chem. Rev. 1991, 91, 893-928. [CrossRef]

43. Portalone, G.; Bencivenni, L.; Colapietro, M.; Pieretti, A.; Ramondo, F.; Møller, J.; Senning, A.; Yao, X.-K.; Wang, H.-G.; Tuchagues, J.-P.; et al. The Effect of Hydrogen Bonding on the Structures of Uracil and Some Methyl Derivatives Studied by Experiment and Theory. Acta Chem. Scand. 1999, 53, 57-68. [CrossRef] 
44. Brunetti, B.; Portalone, G.; Piacente, V. Sublimation Thermodynamic Parameters for 5-Fluorouracil and Its 1-Methyl and 1,3-Dimethyl Derivatives from Vapor Pressure Measurements. J. Chem. Eng. Data 2002, 47, 17-19. [CrossRef]

45. Portalone, G.; Colapietro, M. First example of cocrystals of polymorphic maleic hydrazide. J. Chem. Crystallogr. 2004, 34, 609-612. [CrossRef]

46. Portalone, G.; Colapietro, M. Redetermination of 5-fluorocytosine monohydrate. Acta Crystallogr. Sect. E Struct. Rep. Online 2006, 62, o1049-o1051. [CrossRef]

47. Portalone, G.; Colapietro, M. Asymmetric base pairing in the complex 5-fluorocytosinium chloride/5-fluorocytosine monohydrate. J. Chem. Crystallogr. 2007, 37, 141-145. [CrossRef]

48. Portalone, G.; Colapietro, M. Solid-Phase Molecular Recognition of Cytosine Based on Proton-Transfer Reaction. J. Chem. Crystallogr. 2009, 39, 193-200. [CrossRef]

49. Portalone, G. Supramolecular association in proton-transfer adducts containing benzamidinium cations. I. Four molecular salts with uracil derivatives. Acta Crystallogr. Sect. C Cryst. Struct. Commun. 2010, 66, o295-o301. [CrossRef] [PubMed]

50. Portalone, G. Solid-phase molecular recognition of cytosine based on proton-transfer reaction. Part II. supramolecular architecture in the cocrystals of cytosine and its 5-Fluoroderivative with 5-Nitrouracil. Chem. Central J. 2011, 5, 51. [CrossRef]

51. Portalone, G.; Irrera, S. Supramolecular structure of unnatural nucleobases: Revised structure of (2:1) 6-methylisocytosinium dihydrogen monophosphate adduct. J. Mol. Struct. 2011, 991, 92-96. [CrossRef]

52. Habgood, M.; Price, S.L.; Portalone, G.; Irrera, S. Testing a Variety of Electronic-Structure-Based Methods for the Relative Energies of 5-Formyluracil Crystals. J. Chem. Theory Comput. 2011, 7, 2685-2688. [CrossRef] [PubMed]

53. Portalone, G. 5-Fluorocytosine/isocytosine monohydrate. First example of isomorphic and isostructural co-crystal of py-rimidine nucleobases. Crystals 2020, 10, 999. [CrossRef]

54. Portalone, G.; Rissanen, K. Multifacial recognition in binary and ternary cocrystals from 5-halouracil and aminoazine de-rivatives. Cryst. Growth Des. 2018, 18, 5904-5918. [CrossRef]

55. Portalone, G. Site Selectivity of Halogen Oxygen Bonding in 5- and 6-Haloderivatives of Uracil. Crystals 2019, 9, 467. [CrossRef]

56. Espinosa, E.; Alkorta, I.; Elguero, J.; Molins, E. From Weak to Strong Interactions: A comprehensive analysis of the topological and energetic properties of the electron density distribution involving X-H $\cdots$ F. Y systems. J. Chem. Phys. 2002, 117, 5529-5542. [CrossRef]

57. Espinosa, E.; Molins, E.; Lecomte, C. Hydrogen bond strengths revealed by topological analyses of experimentally observed electron densities. Chem. Phys. Lett. 1998, 285, 170-173. [CrossRef]

58. Bartashevich, E.V.; Tsirelson, V.G. Interplay Between Non-covalent Interactions in Complexes and Crystals with Halogen Bonds. Russ. Chem. Rev. 2014, 83, 1181-1203.

59. Steed, K.M.; Steed, J.W. Packing Problems: High Z' Crystal Structures and Their Relationship to Cocrystals, Inclusion Compounds, and Polymorphism. Chem. Rev. 2015, 115, 2895-2933. [CrossRef] [PubMed]

60. Brock, C.P. High-Z' structures of organic molecules: Their diversity and organizing principles. Acta Crystallogr. Sect. B Struct. Sci. Cryst. Eng. Mater. 2016, 72, 807-821. [CrossRef]

61. Motherwell, W.D.S.; Shields, G.P.; Allen, F.H. Visualization and characterization of non-covalent networks in molecular crystals: Automated assignment of graph-set descriptors for asymmetric molecules. Acta Crystallogr. Sect. B Struct. Sci. 1999, 55, $1044-1056$. [CrossRef] [PubMed]

62. Jenkins, J.L.; Agrawal, A.A.; Gupta, A.; Green, M.R.; Kielkopf, C.L. U2AF65 adapts to diverse pre-mRNA splice sites through conformational selection of specific and promiscuous RNA recognition motifs. Nucleic Acids Res. 2013, 41, 3859-3873. [CrossRef]

63. Agrawal, A.A.; Salsi, E.; Chatrikhi, R.; Henderson, S.; Jenkins, J.L.; Green, M.R.; Ermolenko, D.N.; Kielkopf, C.L. An extended U2AF65-RNA-binding domain recognizes the $3^{\prime}$ splice site signal. Nat. Commun. 2016, 7, 10950. [CrossRef] [PubMed]

64. Wood, P.A.; Olsson, T.S.G.; Cole, J.C.; Cottrell, S.J.; Feeder, N.; Galek, P.T.A.; Groom, C.R.; Pidcock, E. Evaluation of molecular crystal structures using Full Interaction Maps. CrystEngComm 2013, 15, 65-72. [CrossRef]

65. Vologzhanina, A.V. Intermolecular Interactions in Functional Crystalline Materials: From Data to Knowledge. Crystals 2019, 9, 478. [CrossRef]

66. Linden, A. Obtaining the best results: Aspects of data collection, model finalization and interpretation of results in small-molecule crystal-structure determination. Acta Crystallogr. Sect. E Crystallogr. Commun. 2020, 76, 765-775. [CrossRef] [PubMed]

67. Pimentel, G.C.; McClellan, A.L. The Hydrogen Bond; Freeman: San Francisco, CA, USA, 1960; p. 289.

68. Taylor, R.; Kennard, O. Hydrogen-bond geometry in organic crystals. Acc. Chem. Res. 1984, 17, 320-326. [CrossRef]

69. CrysAlis PRO; Rigaku Oxford Diffraction: Yarnton, England, 2018.

70. Burla, M.C.; Caliandro, R.; Camalli, M.; Carrozzini, B.; Cascarano, G.L.; De Caro, L.; Giacovazzo, C.; Polidori, G.; Spagna, R. SIR2004: An improved tool for crystal structure determination and refinement. J. Appl. Crystallogr. 2005, 38, 381-388. [CrossRef]

71. Sheldrick, G.M. Crystal structure refinement with SHELXL. Acta Crystallogr. Sect. C Struct. Chem. 2015, 71, 3-8. [CrossRef] [PubMed]

72. Farrugia, L.J. WingX and ORTEP for Windows: An update. J. Appl. Cryst. 2012, 45, 849-854. [CrossRef]

73. Macrae, C.F.; Bruno, I.J.; Chisholm, J.A.; Edgington, P.R.; McCabe, P.; Pidcock, E.; Rodriguez-Monge, L.; Taylor, R.J.; Van De Streek, J.; Wood, P.A. Mercury CSD 2.0- new features for the visualization and investigation of crystal structures. J. Appl. Crystallogr. 2008, 41, 466-470. [CrossRef] 
74. Turner, M.J.; Mckinnon, J.J.; Wolff, S.K.; Grimwood, D.J.; Spackman, P.R.; Jayatilaka, D.; Spackman, M.A. CrystalEx-plorer17. The University of Western Australia. 2017. Available online: http:/ / hirshfeldsurface.net (accessed on 2 November 2020).

75. Chai, J.-D.; Head-Gordon, M. Long-range corrected hybrid density functionals with damped atom-atom dispersion cor-rections. Phys. Chem. Chem. Phys. 2008, 10, 6615-6620. [CrossRef] [PubMed]

76. Frisch, M.J.; Trucks, G.W.; Schlegel, H.B.; Scuseria, G.E.; Robb, M.A.; Cheeseman, J.R.; Scalmani, G.; Barone, V.; Petersson, G.A.; Nakatsuji, H.; et al. Gaussian 09; Revision A.02; Gaussian, Inc.: Wallingford, CT, USA, 2016.

77. Lu, T.; Chen, F. Multiwfn: A multifunctional wavefunction analyzer. J. Comput. Chem. 2012, 33, 580-592. [CrossRef] [PubMed] 